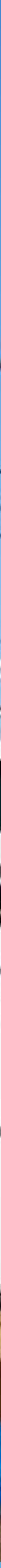

Sociaal-economische gevolgen van een totaal verbod van pulsvisserij voor de Nederlandse visserijsector 



\section{Sociaal-economische gevolgen van een totaalverbod op pulsvisserij voor de Nederlandse visserijsector}

Wim Zaalmink, Geert Hoekstra, Arie Mol en Wouter Jan Strietman 
Wim Zaalmink, Geert Hoekstra, Arie Mol en Wouter Jan Strietman, 2018. Sociaal-economische gevolgen van een totaalverbod op pulsvisserij voor de Nederlandse visserijsector. Wageningen, Wageningen Economic Research, Nota 2018-044. 36 blz.; 9 fig.; 16 tab.; 13 ref.

Deze nota beschrijft de omvang van de pulsvisserij in Nederland, en de sociaal-economische gevolgen wanneer de Nederlandse pulskotters moeten omschakelen naar de boomkorvisserij. De pulsvloot is voor de Nederlandse visserij van groot belang. Als alle pulskotters omschakelen naar boomkor resulteert dat in een forse verlaging van het economisch rendement. Bij lagere schol- en tongprijzen en hogere brandstofprijzen, vergelijkbaar met die in de periode 2012-2014, zou het gemiddelde nettoresultaat nihil zijn. In deze situatie zal de helft van de kotters zelfs een negatief resultaat behalen. Deze afname van de financiële resultaten heeft de volgende effecten op de economie van de visserij:

- door de negatieve resultaten zal de continuïteit van bedrijven in het geding komen

- door de lage deellonen zal het moeilijk zijn gekwalificeerde bemanning aan boord te krijgen

- door de afname van het financiële resultaat zal er minder of geen ruimte meer zijn voor vervanging en vernieuwing.

Trefwoorden: pulsvisserij, sociaal-economische gevolgen, boomkor, nettoresultaat, deelloon

Dit rapport is gratis te downloaden op https://doi.org/10.18174/452306 of op www. wur. nl/economicresearch (onder Wageningen Economic Research publicaties).

(C) 2018 Wageningen Economic Research

Postbus 29703, 2502 LS Den Haag, T 07033583 30, E communications.ssg@wur.nl, www.wur.nl/economic-research. Wageningen Economic Research is onderdeel van Wageningen University \& Research.

\section{(cc) BY-NC}

Wageningen Economic Research hanteert voor haar rapporten een Creative Commons Naamsvermelding 3.0 Nederland licentie.

(C) Wageningen Economic Research, onderdeel van Stichting Wageningen Research, 2018 De gebruiker mag het werk kopiëren, verspreiden en doorgeven en afgeleide werken maken. Materiaal van derden waarvan in het werk gebruik is gemaakt en waarop intellectuele eigendomsrechten berusten, mogen niet zonder voorafgaande toestemming van derden gebruikt worden. De gebruiker dient bij het werk de door de maker of de licentiegever aangegeven naam te vermelden, maar niet zodanig dat de indruk gewekt wordt dat zij daarmee instemmen met het werk van de gebruiker of het gebruik van het werk. De gebruiker mag het werk niet voor commerciële doeleinden gebruiken.

Wageningen Economic Research aanvaardt geen aansprakelijkheid voor eventuele schade voortvloeiend uit het gebruik van de resultaten van dit onderzoek of de toepassing van de adviezen.

Wageningen Economic Research is ISO 9001:2008 gecertificeerd.

Wageningen Economic Research Nota 2018-044 | Projectcode 2282300305

Foto omslag: Shutterstock 


\section{Inhoud}

Woord vooraf $\quad 5$

$\begin{array}{ll}\text { Samenvatting } & 6\end{array}$

S.1 Belangrijkste uitkomsten $\quad 6$

$\begin{array}{lll}\text { S.2 Overige uitkomsten } & 6\end{array}$

$\begin{array}{lll}\text { S.3 Methode } & 6\end{array}$

1

$\begin{array}{ll}\text { Inleiding } & 7\end{array}$

2

$\begin{array}{ll}\text { Data en methodiek } & 8\end{array}$

$\begin{array}{lll}2.1 & \text { Uitwerking van de vraag } & 8\end{array}$

$\begin{array}{lll}2.2 & \text { Data } & 8\end{array}$

2.3 Methode $\quad 8$

$\begin{array}{ll}2.4 & \text { Uitgangspunten }\end{array}$

$\begin{array}{lll}2.5 & \text { Ten slotte } & 9\end{array}$

$3 \quad$ Het economisch belang van de pulsvisserij $r$

$\begin{array}{lll}3.1 & \text { De pulsvloot } & 10\end{array}$

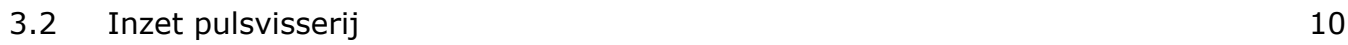

$\begin{array}{ll}3.3 & \text { Aantal bedrijven met pulskotters } \\ 3.4 & 11\end{array}$

3.4 Werkgelegenheid $\quad 12$

$\begin{array}{lll}3.5 & \text { Economisch resultaat } & 12\end{array}$

$\begin{array}{lll}3.6 & \text { Kosten } & 13\end{array}$

$\begin{array}{lll}\text { 3.7 Pulsontheffingen en visserijgemeenschappen } & 14\end{array}$

$4 \quad$ Van puls naar boomkor - economische effecten $\quad 15$

$\begin{array}{lll}4.1 & \text { Inleiding } & 15\end{array}$

4.2 Uitgangspunten bij omschakeling van puls naar boomkor 16

4.3 Gevolgen verandering puls naar boomkor op basis van $2016 \quad 17$

4.4 Resultaten bij verschillende prijsniveaus voor vis en brandstof $\quad 19$

4.5 Gevoeligheidsanalyse voor prijsverschillen $\quad 20$

$5 \quad$ Overige effecten en discussie $\quad 25$

5.1 Overige effecten voor de visserijsector $\quad 25$

5.1.1 Financiële positie van bedrijven $\quad 25$

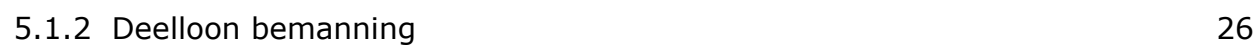

5.1.3 Investeringen, desinvesteringen, onderhoud en nieuwbouw 26

5.1.4 Handelingsruimte voor vissers, vangstsamenstelling en quotum $\quad 27$

5.2 Indirecte effecten op toelevering en verwerking 28

$\begin{array}{lll}5.3 & \text { Discussie } & 28\end{array}$

5.3.1 Kwaliteit basisdata en scenario's $\quad 28$

5.3.2 Visserijgedrag en handelingsperspectief 29

5.3.3 Effecten van andere beleidsmaatregelen (gesloten gebieden, $\begin{array}{ll}\text { aanlandplicht, brexit) } & 29\end{array}$

6 $\begin{array}{ll}\text { Conclusies } & 30\end{array}$

$\begin{array}{ll}\text { Literatuur en websites } & 32\end{array}$

$\begin{array}{ll}\text { Bijlage } 1 & 33\end{array}$ 



\section{Woord vooraf}

De Nederlandse kottervloot experimenteert sinds 2011 op grotere schaal met de pulsvisserij. Deze visserij heeft een aantal voordelen waaronder een lagere bodemberoering en een lager brandstofverbruik. De laatste jaren is de pulsvisserij van groot belang geweest voor de Nederlandse kottersector, juist ook door de lagere brandstofkosten.

Op 16 januari 2018 stemde een grote meerderheid van het Europese Parlement voor een volledig verbod op de pulsvisserij. Een totaalverbod zou grote gevolgen kunnen hebben voor de Nederlandse visserijgemeenschappen.

Het Bestuurlijk Platform Visserij, bestaande uit bestuurlijke vertegenwoordigers van de diverse visserijgemeenschappen (provincies en gemeenten), wil inzicht in de gevolgen van dit verbod voor de ontwikkeling van de visserijgemeenschappen en heeft Wageningen Economic Research gevraagd de sociaal-economische gevolgen op een rij te zetten.

Deze nota beschrijft de uitkomsten. Veel dank is verschuldigd aan de visserijondernemers die gegevens beschikbaar hebben gesteld aan het Bedrijveninformatienet van Wageningen Economic Research. Zonder deze gegevens was het niet mogelijk geweest om deze studie uit te voeren.

Arie Klok van Wageningen Economic Research heeft een belangrijke rol vervuld bij het meelezen en becommentariëren, en het leveren van praktijkkennis.

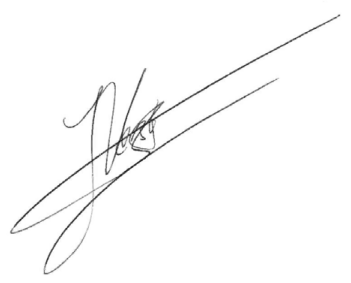

Prof.dr.ir. J.G.A.J. (Jack) van der Vorst Algemeen Directeur Social Sciences Group (SSG)

Wageningen University \& Research 


\section{Samenvatting}

\section{S.1 Belangrijkste uitkomsten}

Als alle pulskotters omschakelen naar boomkor resulteert dat in een forse verlaging van het economisch rendement per kotter en voor de gehele sector. Per eurokotter is de arbeidsopbrengst, dit is het totaal van nettoresultaat en deellonen, iets meer dan 100.000 euro lager en per grote kotter is deze ongeveer 120.000 euro lager. Op sectorniveau, dus voor de Nederlandse vloot, betekent de omschakeling dat de totale arbeidsopbrengst 8,7 miljoen euro lager is, uitgaande van de situatie in 2016.

\section{S.2 Overige uitkomsten}

Voor de betreffende kotters die terugschakelen van puls naar boomkor zijn andere gevolgen:

- een toename van het brandstofverbruik en de $\mathrm{CO}_{2}$-uitstoot met $78 \%$

- een toename van de scholvangst met $69 \%$

- een afname van de tongvangst met $12 \%$

De pulsvloot is voor de Nederlandse visserij van groot belang. Er zijn 79 kotters die de afgelopen jaren met puls hebben gevist. Het nettoresultaat in 2016 van deze pulsvloot bedroeg $38 \%$ van het totaal van de Nederlandse vloot, en $60 \%$ van het totaal van de Nederlandse platvisvloot.

De directe werkgelegenheid van de pulsvisserij heeft een omvang tussen 540 en $600 \mathrm{fte}$. In het jaar 2016 met relatief gunstige visprijzen en lage brandstofprijzen zou er na overschakeling naar boomkor nog een positief resultaat te behalen zijn. Bij lagere schol- en tongprijzen en hogere brandstofprijzen, vergelijkbaar met die in de periode 2012-2014 zou het gemiddelde nettoresultaat nihil zijn. In deze situatie zal de helft van de kotters zelfs een negatief resultaat behalen.

Deze afname van de financiële resultaten heeft drie effecten op de economie van de visserij:

- door de negatieve resultaten zal de continuïteit van bedrijven in het geding komen

- door de lage deellonen zal het moeilijk zijn gekwalificeerde bemanning aan boord te krijgen

- door de afname van het financiële resultaat zal er minder of geen ruimte meer zijn voor vervanging en vernieuwing.

De omschakelingseffecten zijn het grootst voor bemanning en bedrijf. De effecten voor toeleverende en afnemende bedrijven zijn moeilijk te kwantificeren.

\section{S.3 Methode}

In deze studie zijn de sociaal-economische gevolgen op korte termijn van een volledig verbod op pulsvisserij voor de Nederlandse visserijsector onderzocht. De basis voor de beantwoording van deze vraag is het bedrijveninformatienet van Wageningen Economic Research, waarin de daadwerkelijke gegevens van kotterbedrijven zijn vastgelegd. Voor elke pulskotter in dit panel is de omschakeling van puls naar boomkor doorgerekend waarna de uitkomsten zijn gemiddeld en geaggregeerd. Naast de uitgangssituatie van 2016 zijn ook verschillende prijsscenario's doorgerekend om inzicht te krijgen in de prijsgevoeligheid van de uitkomsten. In de studie is geen rekening gehouden met andere ontwikkelingen die eveneens invloed zullen hebben op de visserij zoals aanlandplicht, brexit en ruimtegebruik op de Noordzee. 


\section{$1 \quad$ Inleiding}

Op dinsdag 16 januari 2018 heeft tijdens een stemming in het Europese Parlement een ruime meerderheid gekozen om in te zetten op een volledig verbod op pulsvisserij. Dit besluit heeft grote gevolgen voor de Nederlandse vissersvloot. De Europese Raad van ministers, de Europese Commissie en het Europees Parlement zullen naar verwachting in de loop van 2018 een definitief besluit nemen.

Volgens Europese wetgeving is het vissen met pulstechniek op de Noordzee bij uitzondering toegestaan, en alleen mogelijk onder voorwaarde van wetenschappelijk onderzoek naar deze visserijtechniek. Sinds 2011 zijn in meerdere rondes ontheffingen verleend (Haasnoot et al., 2016) aan de Nederlandse kottervloot voor het verrichten van wetenschappelijk onderzoek naar de voor- en nadelen van deze techniek (Quirijns et al., 2013; Teal et al., 2014). In 2011 zijn er in totaal 42 experimentele pulsontheffingen toegekend door de Europese Unie (EU) aan de Nederlandse visserij. Deze eerste 42 ontheffingen zijn verleend op basis van artikel 43, 850/1998. Dit is een Europese regulering voor het behoud van visbestanden via technische maatregelen bedoeld voor de bescherming van jonge mariene organismes (Council of the European Union, 1998; Rijksoverheid, 2010). In 2014 werden nog eens 42 ontheffingen toegekend waarmee het totaal aantal pulsontheffingen op 84 kwam. Deze laatste 42 ontheffingen zijn verleend gebaseerd op artikel 14 en 15 (beiden gerelateerd aan de aanlandplicht) met als doel om alle praktische methoden volledig te verkennen voor het vermijden, minimaliseren en elimineren van ongewenste visvangsten (Rijnsdorp et al., 2014).

Het Bestuurlijk Platform Visserij, met daarin vertegenwoordigers van Visserij gemeentes en de Provincies is zich bewust van de ernstige gevolgen van het verbod op pulsvisserij en wil graag zicht op de sociaal-economische gevolgen van een volledig pulsverbod voor de Nederlandse visserij. Wageningen Economic Research is gevraagd hierin inzicht te geven.

De kernvraag is:

'Wat zijn de sociaal-economische gevolgen op korte termijn van een volledig verbod op pulsvisserij voor de Nederlandse visserijsector?'

Deze vraag wordt beantwoord vanuit het perspectief dat de huidige kotters/bedrijven die pulsen teruggaan naar de boomkorvisserij. Dit betreft in totaal 84 ontheffingen waarvan er per 31 december 201676 benut werden voor de pulsvisserij op de platvis en 3 voor de garnalenvisserij. De gespecialiseerde garnalenpulskotters zijn bij deze studie niet meegenomen bij de uitkomsten. Deze vergunningen zijn tot nu toe slechts gedeeltelijk benut.

De aandacht is in deze studie gericht op de directe effecten voor de (kotter)visserij en de effecten op bedrijfsresultaat en deellonen voor bemanning; de mogelijke effecten op de toeleverende en verwerkende bedrijven worden kwalitatief benoemd maar niet berekend.

Bij deze studie wordt niet ingegaan op andere (toekomstige) ontwikkelingen die voor de visserij van belang kunnen zijn zoals brexit, windparken en de aanlandplicht.

Dit voorliggende rapport is als volgt samengesteld: hoofdstuk 2 beschrijft de aanpak en de gebruikte gegevensbronnen. Hoofdstuk 3 beschrijft de economische waarde van de Nederlandse pulsvisserij, met daarbij de omvang van vangsten, besomming, kosten en bedrijfsresultaten. Hoofdstuk 4 gaat in op de bedrijfseconomische effecten wanneer de huidige Nederlandse pulskotters terugschakelen van de pulsvisserij naar de boomkor. Hierbij wordt ook inzicht gegeven in de economische effecten bij verschillende prijsniveaus van brandstof en vis.

Hoofdstuk 5 beschrijft overige aspecten en plaatst mogelijke gevolgen van een pulsverbod in een breder kader. Hoofdstuk 6 beschrijft de conclusies van de studie. 


\section{Data en methodiek}

\section{$2.1 \quad$ Uitwerking van de vraag}

Bij een totaalverbod op de pulsvisserij zullen de huidige Nederlandse kotters die met puls vissen om moeten schakelen naar een andere visserijtechniek. Het meest voor de hand liggende alternatief op dit moment is de omschakeling (voor de meeste kotters een terugschakeling) naar de boomkorvisserij. In de periode voor omschakeling was een aantal kotters overgeschakeld van boomkor naar sumwing; sumwing ging gepaard met lagere brandstofkosten maar ook een lagere schol- en tongvangst. Brandstofbesparing was in die periode erg belangrijk. Sumwing vraagt ook een hogere investering. Voor de eenvoud wordt in deze studie uitgegaan dat alle kotters teruggaan naar de boomkormethode. Andere visserijmethoden zijn op dit moment voor deze kotters nauwelijks voorhanden omdat de regelgeving en vergunningen dit niet toelaten.

De vragen met betrekking tot het volledige pulsverbod en de sociaal-economische gevolgen zijn de volgende:

a. Wat is op dit moment de omvang van de pulsvisserij in Nederland en de verdeling daarvan over de Nederlandse kustgemeenschappen?

b. Wat is voor de huidige pulskotters het verschil in economisch rendement tussen de pulsvisserij en de boomkorvisserij bij verschillende prijsniveaus van vis en brandstof?

c. Wat zijn te verwachten neveneffecten bij een totale omschakeling voor de visserij en de visserij gerelateerde regio's?

\subsection{Data}

Voor de uitgangspunten met betrekking tot puls en boomkor is vooral de website www.pulsefishing.eu geraadpleegd. De beschrijving van de omvang van de pulsvisserij is gebaseerd op een factsheet die Wageningen Economic Research in 2018 heeft gepubliceerd (Van Oostenbrugge et al., 2018). Daarnaast zijn officiële logboekgegevens (VIRIS) en gegevens uit het vlootregister (CVR) gebruikt voor de analyse van de vangstgegevens en de vlootomvang.

Voor de bepaling van de economische effecten van omschakeling is gebruikgemaakt van de visserijgegevens van het Bedrijveninformatienet van Wageningen Economic Research en de daaraan gekoppelde website www.visserijincijfers.nl. Ten tijde van de uitvoering van deze studie waren voor het jaar 2016 de gegevens van 30 pulskotters beschikbaar.

Daarnaast is tijdens het onderzoek een belronde gehouden bij een aantal visserij-ondernemers en toeleverende bedrijven om na te gaan hoe zij het effect van het verbod voor de visserijbedrijven inschatten, hoe zij op de veranderingen zullen inspelen en of zij nieuwe investeringen en aanvullende kosten verwachten, en zo ja de hoogte hiervan. Hiervoor zijn 15 visserij ondernemers vanuit diverse regio's benaderd, en daarnaast 4 toeleverende bedrijven zoals coöperaties en motorenleveranciers. De verkregen informatie is gebruikt om het ondernemersgedrag en de resultaten te toetsen.

\section{$2.3 \quad$ Methode}

Per visserijbedrijf (kotter) zijn vanuit het Bedrijveninformatienet (gegevens 2016) berekeningen uitgevoerd vanuit de situatie dat de betreffende kotter zou omschakelen van puls naar boomkor. Hierbij is uitgegaan van de kosten, opbrengsten en vangstgegevens die van deze kotters in het informatienet beschikbaar zijn. Vervolgens zijn deze resultaten geaggregeerd naar de Nederlandse vloot op basis van het totaal aantal schepen in twee groepen (zie hoofdstuk 4). 
Bij de berekening van de uitkomsten is aandacht besteed aan:

1. Verschil in kosten/opbrengsten en nettoresultaat, inclusief noodzakelijke investeringen en kosten voor terugkeer naar de boomkorvisserij. Denk aan boomkortuigen, extra onderhoud motoren en overige investeringen.

2. Inkomsten voor opvarenden (deelloon voor schipper en bemanning).

3. $\mathrm{CO}_{2}$-uitstoot.

4. Gevoeligheid van kosten/opbrengsten voor verschillende brandstof- en visprijzen. Hierbij is een analyse gemaakt van de prijsniveaus in de afgelopen jaren. Op basis van deze analyse is voor twee extreme situatie geanalyseerd was de gevolgen van omschakeling zullen zijn.

\subsection{Uitgangspunten}

Er is veel vergelijkend onderzoek gedaan naar de verschillen tussen puls, sumwing en boomkor op het gebied van ecologie en economie. Het meest recente rapport over de economische verschillen tussen puls en boomkor is het onderzoek van Taal en Klok (2014). Hieruit komen de volgende verschillen naar voren van de pulswing ten opzichte van de boomkor:

1. $14 \%$ meer tongvangst (in $\mathrm{kg}$ )

2. $41 \%$ minder scholvangst (in $\mathrm{kg}$ )

3. Lagere totale vangsthoeveelheid $(-33 \%)$

4. Hogere afslagprijs voor tong ( $+5 \%)$ en schol $(+7 \%)$

5. Lagere besomming per zeedag $(-5 \%)$

6. $48 \%$ minder gasolieverbruik

7. Hogere (deel)lonen (+19\%)

8. Hogere vistuigkosten (inclusief afschrijving op de aanschaf) $(+68 \%)$.

Ook op Visserij in Cijfers staan resultaten van puls ten opzichte van boomkor vermeld, deze liggen in de dezelfde orde van grootte als hiervoor genoemd. In het jaar 2016 bleek het brandstofverbruik op jaarbasis bij puls 44\% lager dan bij boomkor, en 32\% lager dan bij de sumwing.

Naast de verschillen in de jaarlijkse kosten die hierboven beschreven zijn (inclusief afschrijvingen en onderhoud) zijn bij overschakeling van de pulskotters naar de boomkor de financiële middelen nodig om nieuwe tuigen en netten aan te schaffen. De investeringen hierin bedragen gemiddeld circa 100.000 euro per grote kotter en 75.000 euro per eurokotter (interviews met visserijbetrokkenen).

In dit rapport worden verschillende kengetallen gebruikt. Deze worden hier als volgt gedefinieerd:

- nettoresultaat: opbrengsten minus kosten, dus bedrijfswinst

- deellonen: totaal van deellonen van bemanning en schipper

- arbeidsopbrengst: som van deellonen en nettoresultaat

- kosten: alle kosten inclusief de deellonen

- technische kosten: kosten exclusief de deellonen

- fte: fulltime-equivalent. Eén fte is een volledige werkweek. Eurokotters kennen 4 fte aan boord en grote kotters 6-7 fte.

\subsection{Ten slotte}

Opgemerkt moet worden dat deze studie gebaseerd is op technische- economische data van kotterbedrijven vanuit het Bedrijveninformatienet van Wageningen Economic Research. De veranderingen die optreden bij omschakeling van puls naar boomkor zijn daarbij rechttoe rechtaan doorgerekend, ervan uitgaande dat het gedrag van de ondernemers niet zal veranderen. In de praktijk zullen ondernemers zich altijd aanpassen aan veranderende omstandigheden en zoeken naar de meest optimale weg om eventuele nadelige gevolgen zoveel mogelijk te ontzien. Dit geldt ook voor visserijondernemers die hun weg zullen zoeken. De gepresenteerde resultaten zijn dan ook geen prognose maar geven wel een goed beeld van de gevolgen bij verder ongewijzigd beleid en ongewijzigd ondernemersgedrag. Bij de interpretatie van de resultaten moet hiermee rekening worden gehouden. 


\section{Het economisch belang van de pulsvisserij}

\subsection{De pulsvloot}

De Nederlandse kottersector bestond eind 2016 uit 280 kotters, waarvan 143 garnalenkotters. De resterende groep van 137 kotters bestond uit 14 flyshooters, 54 euro- en middenslagkotters (270 tot $1.500 \mathrm{pk})$ en 69 grote kotters (1.500-2.000 pk).

Tabel 3.1 geeft het overzicht van de Nederlandse vloot en het aantal pulsontheffingen per categorie voor eind 2016 (bron: Oostenbrugge et al., 2018). In het jaar 2017 hebben er geen veranderingen plaatsgevonden in het aantal (benutte) pulsontheffingen, wel is de totale kottervloot (exclusief de garnalenkotters) in 2017 met vijf schepen (inclusief één flyshooter) toegenomen.

De pulsvisserij is voor de Nederlandse kottersector van groot belang. Eind 2016 heeft $83 \%$ van de grote kotters een pulsontheffing, $44 \%$ van de euro- en middenslagkotters en $2 \%$ van de garnalenkotters. In totaal beschikken 84 kotters over een pulsontheffing waarbij 79 van de 84 kotters hun verleende pulsontheffing actief hebben ingezet, waaronder 3 garnalenkotters (zie tabel 3.1). Deze 79 schepen vormen $28 \%$ van de totale kottervloot. Wanneer de garnalenkotters niet meegerekend worden dan maken de 76 pulskotters samen 55\% uit van de ongeveer 137 actieve kotters.

Tabel 3.1 Aantal actieve kotters en aantal pulsontheffingen (per 31-12-2016)

\begin{tabular}{|c|c|c|c|c|c|}
\hline & Euro/Midden & Groot & Flyshoot & Garnalen & Totaal \\
\hline $\begin{array}{l}\text { Pulsontheffingen niet in } \\
\text { gebruik per } 31-12-2016 \text { a) }\end{array}$ & - & 2 & - & 1 & 3 \\
\hline Pulsontheffingen onbenut & 5 & - & - & - & 5 \\
\hline Totaal pulsontheffingen & 24 & 57 & - & 3 & 84 \\
\hline $\begin{array}{l}\text { Omvang hele vloot, met of } \\
\text { zonder ontheffing }\end{array}$ & 54 & 69 & 14 & 143 & 280 \\
\hline $\begin{array}{l}\% \text { van de vloot met } \\
\text { pulsontheffing }\end{array}$ & 44 & 83 & 0 & 2 & 30 \\
\hline
\end{tabular}

Toelichting:

- Euro/Midden: schepen met een motorvermogen tussen 270 en 1.500 pk die meerdere takken van visserij uitoefenen. Eén kotter beschikt ook over een garnalenpulsontheffing.

- Groot: schepen van meer dan 1.500 pk die zich voornamelijk op platvis richten met de oomkor/pulsvisserij, of twinrigvisserij.

- Flyshoot: schepen die de flyshootvisserij uitoefenen.

- Garnalen: schepen met een motorvermogen van 300 pk of minder die zich volledig of vooral op de garnalenvisserij richten.

a) Deze twee ontheffingen (die wel benut zijn) behoren bij schepen met een bepaald registratienummer die per 31-12-2016 niet meer onder dat nummer op de vlootlijst vermeld stonden.

Bron: Nederlands Register van Vissersvaartuigen, toegepast door Wageningen Economic Research, Oostenbrugge et al. (2018).

\subsection{Inzet pulsvisserij}

Naast de omvang van pulsvisserij in het aantal schepen, is ook de vlootinzet een methodiek om de omvang van een visserijtechniek te kunnen vergelijken. De vlootinzet wordt uitgedrukt in het aantal PK-dagen, dit is het motorvermogen zoals geregistreerd in het Nationaal Visserij Register vermenigvuldigd met het aantal gemaakte zeedagen. Sinds de introductie van de puls is het aandeel van de pulsvisserij sterk toegenomen. In 2011 (zie figuur 3.1) bestond de vlootinzet (exclusief 
garnalenvisserij) voor $29 \%$ uit pulsvisserij op het totaal van 33,5 miljoen pk-dagen (exclusief garnalen). In 2016 bestond de vlootinzet voor $68 \%$ uit pulsvisserij op het totaal van 29,9 miljoen pkdagen (exclusief garnalenvisserij).

\subsection{0}

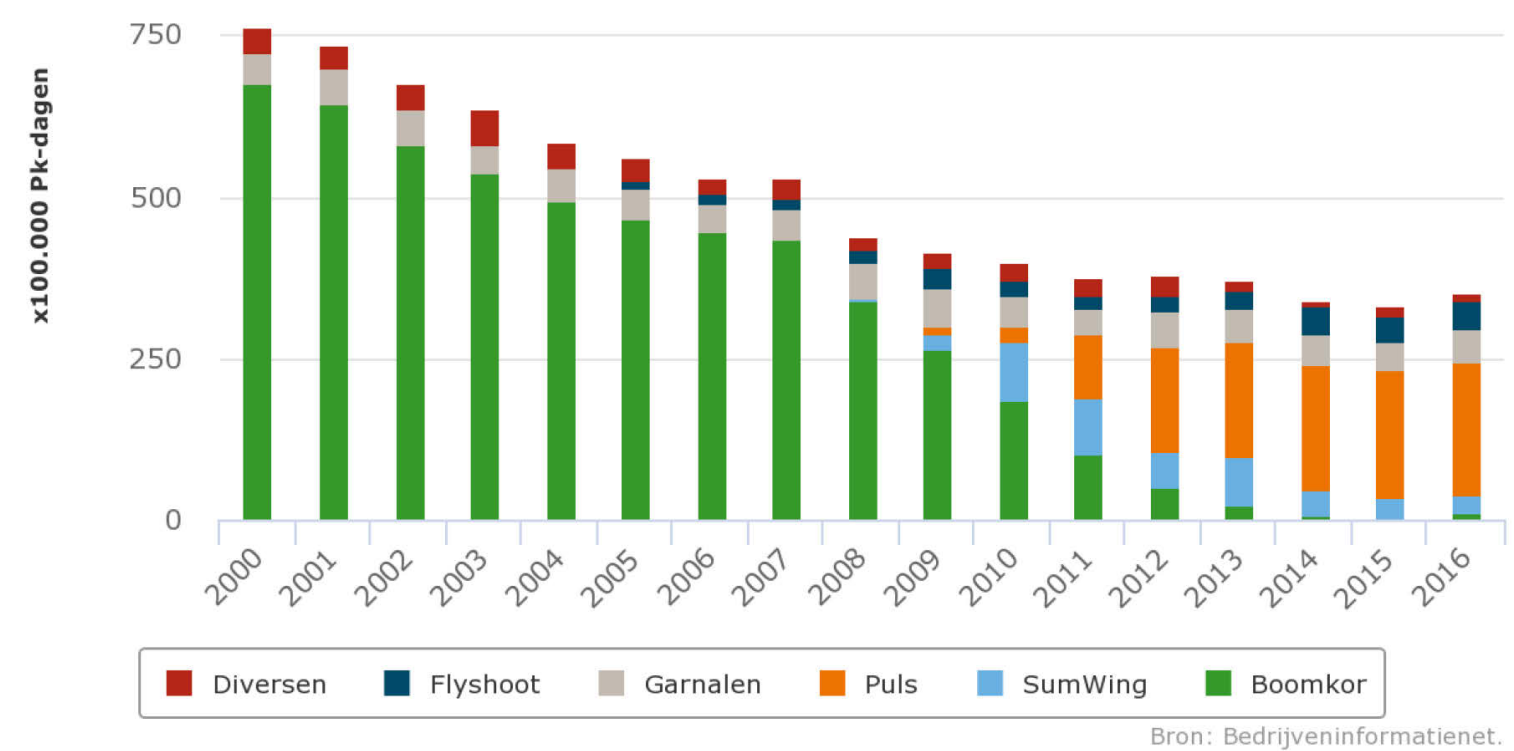

Figuur 3.1 Vlootinzet per vistechniek

\subsection{Aantal bedrijven met pulskotters}

In totaal waren er in 2016 naar schatting 98 bedrijven met een belang in de actieve Nederlandse kottervloot (exclusief bedrijven met alleen garnalenkotters). Hiervan waren er 64 bedrijven met één of meer pulskotters. Bedrijven met pulskotter(s) maken ongeveer $61 \%$ van de actieve kottervloot uit. De overige $39 \%$ van de actieve kottervloot bestond uit bedrijven die geen pulskotter(s) bezitten (zie tabel 3.2).

Tabel 3.2 Aantal bedrijven met of zonder actieve pulskotter(s) (per 31-12 2016)

\begin{tabular}{lll} 
Kotterbedrijven (exclusief garnalenkotters) & Aantal bedrijven & Aantal kotters \\
Met 1 pulskotter & 56 & 56 pulskotters \\
\hline Met 2 pulskotters & 6 & 12 pulskotters \\
\hline Met 3 of meer pulskotters & 2 & 8 pulskotters \\
\hline $\begin{array}{l}\text { Totaal aantal kotterbedrijven (exclusief garnalenkotters a) met } \\
\text { pulskotter(s) }\end{array}$ & $\mathbf{6 4}$ & $\mathbf{7 6}$ pulskotters b) \\
\hline $\begin{array}{l}\text { Totaal aantal geschatte } \text { kotterbedrijven (inclusief flyshooters, } \\
\text { exclusief garnalenkotters a) met of zonder pulskotter(s) }\end{array}$ & $\mathbf{9 8}$ & $\mathbf{1 3 7}$ kotters
\end{tabular}

a) Drie bedrijven bezitten een actieve pulsgarnalenkotter waarvan twee actief in gebruik per 31-12-2016;

b) exclusief 3 garnalenpulskotters. 


\subsection{Werkgelegenheid}

De Nederlandse kottervloot biedt werk aan 1.162 fte, verdeeld over de 280 kotters in 2016 (www.visserijincijfers.nl). Exclusief de garnalenkotters komt de werkgelegenheid op 733 fte in 2016. De pulsvloot bestond in 2016 uit ongeveer 340-400 fte bij de grote kotters en $80 \mathrm{fte}$ bij de eurokotters, dus in totaal $420-480 \mathrm{fte}$. Dit is $57 \%-65 \%$ van de totale aantal opvarenden in de actieve Nederlandse kottervloot (exclusief garnalenkotters).

Naast het aantal opvarenden kent bijna ieder kotterbedrijf vaak nog één of twee mannen aan wal die onderhoud plegen aan netten en of bedrijfstechnische zaken aan wal managen. Vaak vissen deze mannen niet meer maar staan nog wel op de loonlijst of participeren in het eigendom/aandelen van het bedrijf. Schattingen uit het Bedrijveninformatienet en de interviews leiden tot circa 1,5 werknemers/mede-eigenaars aan de wal. Voor 2016 komt daarmee het geschatte aantal Nederlandse huishoudens dat afhankelijk is van de pulsvisserij op circa 540 tot 600 .

\subsection{Economisch resultaat}

\section{Nettoresultaat}

Het nettoresultaat (verschil tussen totale opbrengsten en totale kosten) van de totale actieve kottervloot bedroeg in $201680,5 \mathrm{mln}$. euro en $51,1 \mathrm{mln}$. euro exclusief de garnalenvloot. De pulskotters leverden hieraan een bijdrage ter waarde van $30,8 \mathrm{mln}$. euro en zorgden voor $38 \%$ van het totale nettoresultaat inclusief de garnalenvloot en $60 \%$ exclusief de garnalenvloot.

\section{Opbrengsten}

Doordat pulsvisserij een gerichte tongvisserij is, heeft er sinds de toepassing van de puls een verschuiving plaatsgevonden in de visserij van schol naar tong. Qua vangstgewicht is schol echter nog steeds de belangrijkste soort in de pulsvisserij. In 2016 landden de pulskotters ongeveer $7.1 \mathrm{mln}$. kg tong aan en $9.6 \mathrm{mln}$. $\mathrm{kg}$ schol. Voor de pulsvisserij is de tong veel belangrijker dan voor de andere visserijen. Bij de pulsvisserij maakt tong 31\% uit van de vangst, terwijl dit voor de totale visserij $11 \%$ is.

Van de totale aanvoer van de kottersector droeg de puls voor $75 \%$ bij aan de aanvoer van tong en $29 \%$ van de aanvoer van schol. In 2016 was de pulsvloot van 80 kotters verantwoordelijk voor 54\% van de besomming van de actieve kottervloot exclusief garnalen (zie tabel 3.3).

\section{Tabel 3.3 Besomming (aanvoerwaarde) in 2016 (exclusief garnalen)}

\begin{tabular}{|c|c|c|c|}
\hline Vissoort & Totale kottervloot & Pulskotters & $\begin{array}{l}\% \text { Puls ten } \\
\text { opzichte van totaal }\end{array}$ \\
\hline Schol & $53,899,000$ & $€ \quad 15,366,000$ & 29 \\
\hline Overige vis & $€ \quad 51,100,000$ & $20,279,000$ & 40 \\
\hline Totale waarde & $€ \quad 204,538,000$ & $€ \quad 110,203,000$ & 54 \\
\hline
\end{tabular}

Bron: VIRIS, toegepast door Wageningen Economic Research. 


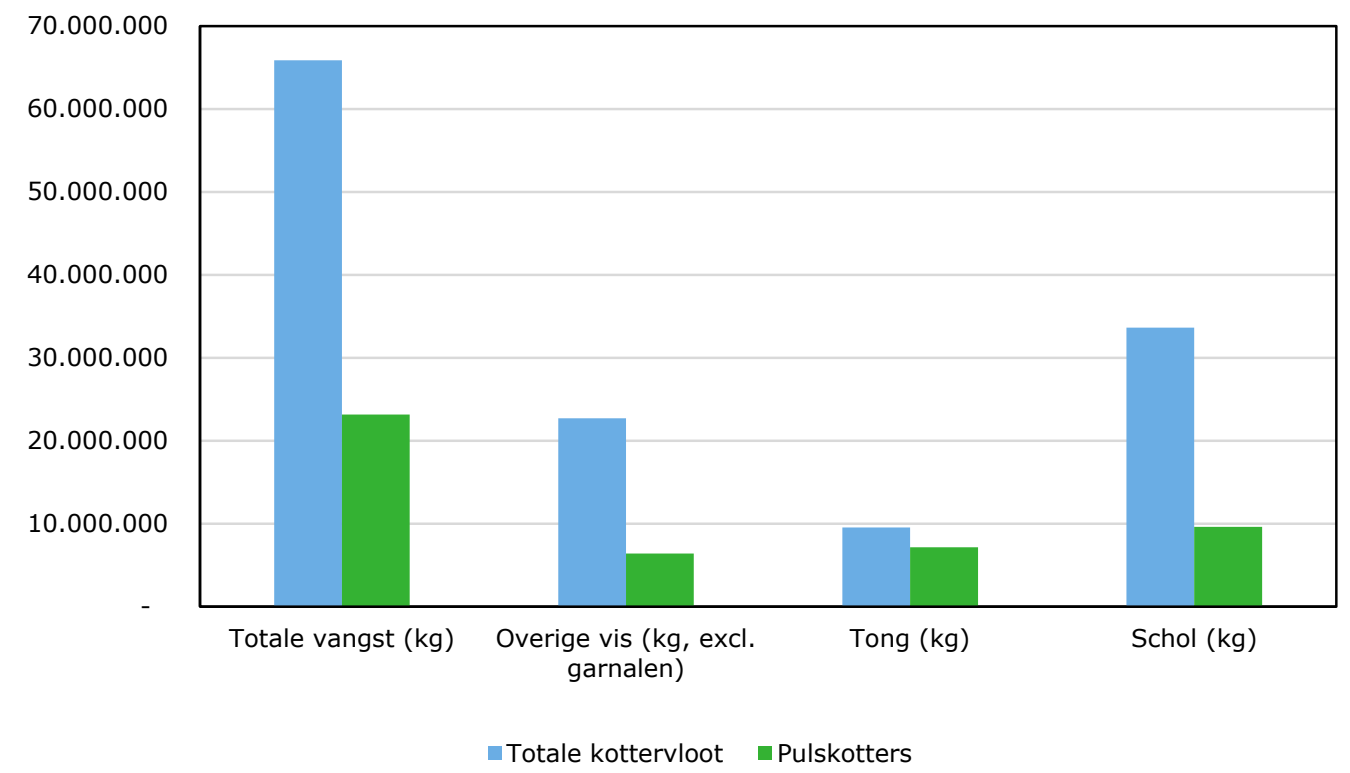

Figuur 3.2 Aanvoer gevangen vis (levend gewicht in kg) in 2016 (exclusief garnalen) Bron: VIRIS, bewerkt door Wageningen Economic Research.

\subsection{Kosten}

Naast de eerdere investeringen in het aankopen van het schip en meerdere vergunningen (onder andere vangstrechten oftewel quota) moet een bedrijf ook meerdere aanpassingen aan het schip laten uitvoeren om te kunnen pulsvissen. Denk dan onder andere aan de ombouw van het schip en aanpassingen aan het netwerk en vistuig. De gemiddelde investeringen voor pulstuigen per pulskotter en voor alle 80 pulsschepen in totaal staan in tabel 3.4 genoemd.

Tabel 3.4 Gemiddelde aanschafwaarde pulssysteem per kotter

$\begin{array}{llcc}\text { Gemiddeld per schip } & & \text { Aantal pulskotters } & \text { Total (op basis van vloot 2016) } \\ \text { Kleine/middelkotter } & € 250.000 & 22 & € 5.500 .000 \\ \text { Grote kotter } & € 350.000 & 57 & € 19.950 .000\end{array}$

Bron: Bedrijveninformatienet (Wageningen Economic Research).

\section{Onderhoudskosten}

De pulstuigen hebben hogere kosten van onderhoud en afschrijving dan de boomkortuigen. In Visserijincijfers worden deze kosten niet uitgesplitst maar uit voorgaand onderzoek (Taal en Klok, 2014) blijkt dat de jaarkosten van pulstuig 68\% hoger zijn dan het traditionele tuig.

\section{Brandstofverbruik en -kosten}

Het brandstofverbruik per zeedag verschilt sterk per type vistuig en is voor de pulsvisserij veel lager dan voor de andere platvistuigen. In 2016 lag het brandstofverbruik per zeedag voor grote kotters bij het gebruik van pulstechniek 44\% lager dan bij het gebruik van de boomkortechniek, en $32 \%$ lager dan bij het gebruik van de SumWingtechniek (zie tabel 3.5). Dit verschil is mede afhankelijk van de brandstofprijs, omdat gebleken is dat kotters met boomkor en SumWing bij hoger brandstofprijzen met lagere snelheid gaan vissen, met als gevolg een iets lager brandstofverbruik (Poos et al., 2013). 
Tabel 3.5

Brandstofverbruik per zeedag in liters bij 1.500-2.000 pk kotter (afgerond)

\begin{tabular}{llll} 
jaar & Boomkor & Sumwing & Pulstuig \\
2011 & 7.900 & 6.700 & 3.900 \\
\hline 2016 & 7.300 & 6.000 & 4.100 \\
\hline
\end{tabular}

Bron: Bedrijveninformatienet (Wageningen Economic Research).

Dit lagere verbruik in de pulsvisserij levert ook een aanzienlijke besparing op in de brandstofkosten. Als rekenvoorbeeld: bij een gemiddelde gasolieprijs van 0,34 euro in 2016 bedroegen de brandstofkosten 2.482 euro en 1.394 euro per zeedag respectievelijk voor de boomkor en pulstuig (gemiddeld van eurokotter/middenslagkotter en grote kotter). Bij gemiddeld 181 zeedagen per jaar zijn deze bedragen respectievelijk 449.242 euro en 252.314 euro, een verschil dus van bijna 200.000 euro per kotter per jaar.

\subsection{Pulsontheffingen en visserijgemeenschappen}

Figuur 3.3 geeft de verdeling van de pulsontheffingen over de verschillende havens weer. Urk heeft met 19 de meeste ontheffingen, van de totale vloot op Urk is $43 \%$ puls, gevolgd door Goedereede met 12 ontheffingen en Arnemuiden met 10 ontheffingen.
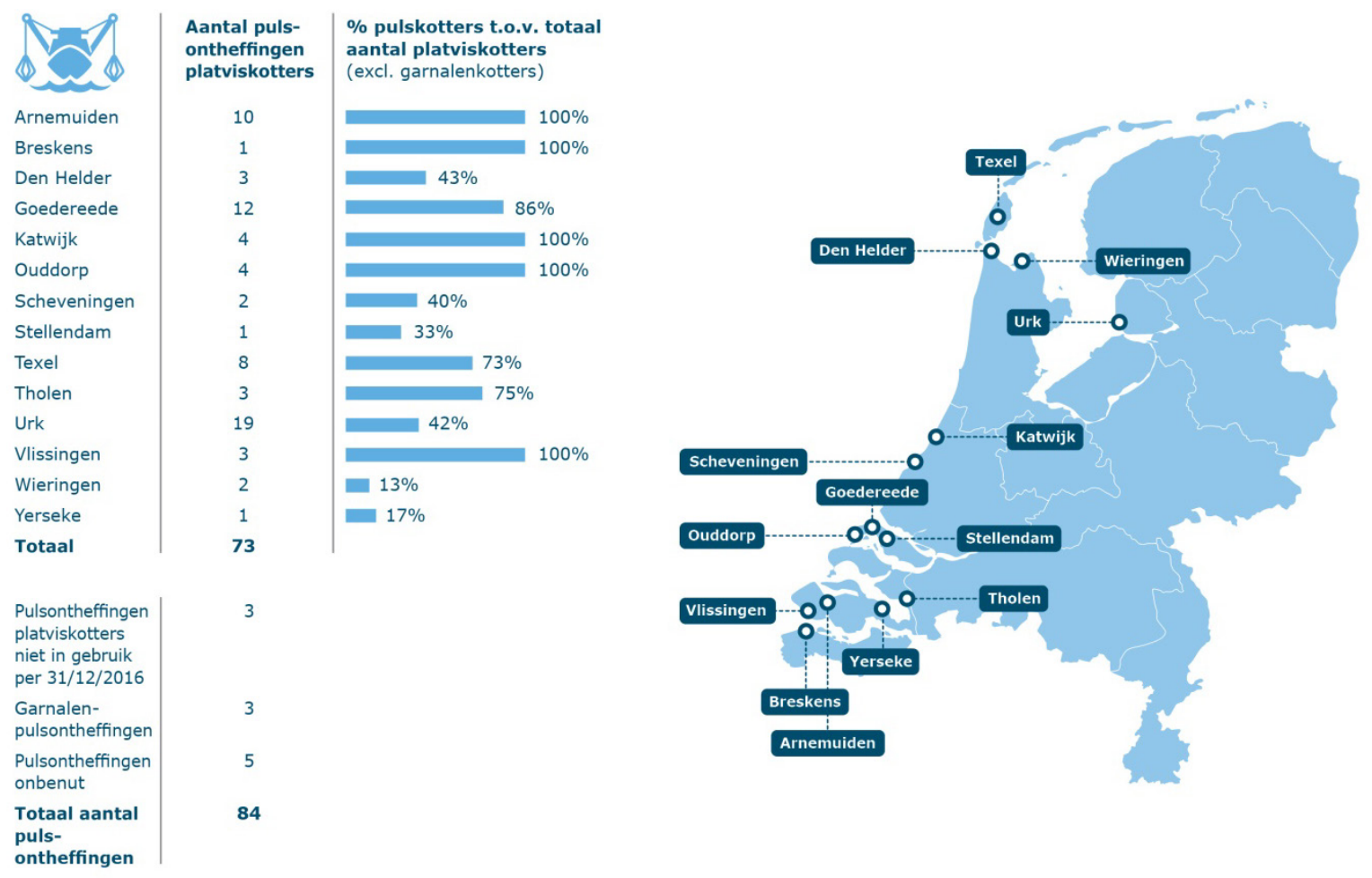

Figuur 3.3 Verdeling van de pulsontheffingen over de visserijgemeenschappen Bron: Oostenbrugge et al. (2018). 


\section{$4 \quad$ Van puls naar boomkor - economische effecten}

\subsection{Inleiding}

Dit hoofdstuk beschrijft de uitkomsten van berekeningen over het pulsverbod onder de veronderstelling dat de huidige pulskotters omschakelen naar een andere visserijmethode. Zoals in hoofdstuk 2 beschreven wordt hierbij gebruik gemaakt van de individuele bedrijfsgegevens van eurokotters en grote kotters die via het Bedrijven Informatie Net beschikbaar zijn (jaar 2016).

Een volledig verbod op pulsvisserij zal betekenen dat de huidige pulskotters zullen kiezen voor een andere visserijmethode. Het meest voor de hand liggende alternatief op dit moment is de omschakeling (ofwel terugschakeling) naar de boomkorvisserij. Dit omdat in de periode voordat met de puls kon worden gevist (voor 2011) door een aantal kotters met sumwing of twinrig werd gevist, maar de meeste pulskotters met de boomkor. Deze omschakeling naar boomkor gaat ook gepaard met de laagste extra kosten en investeringen. Andere visserijmethoden zijn op dit moment voor deze kotters nauwelijks voorhanden omdat de regelgeving en vergunningen dit niet toelaten.

Met behulp van de parameters die veranderen (brandstof, vangstsamenstelling en hoeveelheid, onderhoud, investeringen) kan dan per kotter worden berekend wat dit betekent in het economisch resultaat. Vervolgens worden de resultaten gegroepeerd per kottergrootte (eurokotter vs grote kotter) en worden ze geaggregeerd naar het totaal van de Nederlandse pulsvloot.

Voor de berekening is onderscheid gemaakt in twee groepen:

a. de eurokotters (<300 pk), die naast visserij op platvis ook op andere doelsoorten kunnen vissen (met name garnalen)

b. de grote kotters (1.500-2.000 pk) die (bijna) volledig met boomkor c.q. pulstuig vissen.

Deze indeling in categorieën is niet helemaal sluitend omdat er ook kotters zijn in de range van 300$1.500 \mathrm{pk}$ (middenslagkotters) waarvan het niet altijd duidelijk is in welke categorie deze vallen. De pulskotters met teruggestelde motoren zijn meegenomen in de categorie grote kotters.

Voor beide groepen geldt dat de kotters gedurende het visjaar kunnen wisselen van pulsvisserij naar een andere visserij, waardoor ze niet het gehele jaarrond met de puls behoeven te vissen. Kotters kunnen bijvoorbeeld wisselen naar garnalenvisserij (zonder puls), kreeftjesvisserij, bordenvisserij, of kiezen voor een scholvisserij met twinrig, boomkor of sumwing. De keuze hiervoor is afhankelijk van de beschikbare tong- en scholquota, de vangbaarheid van schol en tong en van de koop- en huurprijzen van quota.

Bij de modelberekeningen is uitgegaan van de visserijactiviteiten in 2016, het meest recente jaar waarvan de individuele economische gegevens beschikbaar zijn. Er is bij kotters die gedeeltelijk ook zonder puls op andere doelsoorten hebben gevist hiervoor gecorrigeerd, met andere woorden er is alleen gerekend met de daadwerkelijke pulsdagen van het jaar 2016.

De meest belangrijke kengetallen van de uitgangssituatie staan in tabel 4.1 vermeld. Dit betreft dus alleen de kotters die in 2016 deels of volledig gepulst hebben. 
Tabel 4.1 Kenmerken en resultaten van de pulskotters in 2016, opgesplitst naar eurokotters en grote kotters - de uitgangssituatie

\begin{tabular}{lll}
\hline Groep & Puls $<300$ pk (eurokotters) & Puls (1,500 - 2,000 pk) \\
\hline Aantal zeedagen per kotter & Per zeedag & 215 (193 puls) \\
\hline Brandstofverbruik per zeedag (I) & 184 (135 puls) & 4.064 (puls) \\
\hline Kg schol per zeedag (puls) & 1753 (puls) & 1.074 \\
\hline Kg tong per zeedag (puls) & 263 & 637 \\
\hline Netto-overschot per jaar (euro) & 552 & 538.000 \\
\hline Deelloon per jaar (euro) & 283.000 & 624.000 \\
\hline Deelloon per bemanningslid per jaar (euro) & 406.000 & 105.000 \\
\hline Gem. brandstofprijs (euro/l) & 101.000 & 0,34 \\
\hline Gem. scholprijs (euro/kg) & 0,34 & 1,66 \\
\hline Gem. tongprijs (euro/kg) & 1,60 & 11,08 \\
\hline Aantal NL kotters & 11,01 & 56 \\
\hline Aantal zeedagen totaal van deze NL kotters & 3.680 & 12.019 \\
\hline Aantal zeedagen puls van deze NL kotters (2016) & 2.712 & 10.836
\end{tabular}

\subsection{Uitgangspunten bij omschakeling van puls naar boomkor}

De uitgangspunten voor de berekeningen zijn in hoofdstuk 2 beschreven. De procentuele verandering van omschakeling van puls naar boomkor staan in tabel 4.2. Deze tabel moet als volgt gelezen worden:

Bij omschakeling van puls naar boomkor is het gasolieverbruik per zeedag bij boomkor $192 \%$ ten opzichte van het gasolieverbruik bij puls, de scholvangsten zijn 169\% enzovoort.

Tabel 4.2 Procentuele verandering bij omschakeling van puls naar boomkor

\begin{tabular}{ll} 
Kosten/opbrengstenpost & Puls naar boomkor (\%) \\
Gasolie & 192 \\
\hline Schol & 169 \\
\hline Tong & 88 \\
\hline Vistuigkosten & 60
\end{tabular}

Bij de omschakeling naar boomkor worden in de literatuur ook andere veranderingen genoemd die optreden, zoals:

- hogere visprijzen voor met puls gevangen vis

- minder discards bij puls

- nieuwe investeringen in boomkor

- extra onderhoud motoren als gevolg van extra afgenomen vermogen

Bij de modelberekeningen is met deze veranderingen geen rekening gehouden, in de discussie paragraaf worden deze veranderingen nader toegelicht. 


\subsection{Gevolgen verandering puls naar boomkor op basis van 2016}

In deze paragraaf worden de uitkomsten beschreven van de omschakeling op basis van de prijsniveaus van het jaar 2016. In de volgende paragrafen wordt inzicht gegeven in andere prijsniveaus van vis en brandstof.

Tabel 4.3 geeft een overzicht van de effecten van de overstap van een gemiddelde pulskorkotter van de pulskorvisserij naar de boomkorvisserij. Te zien is dat de overstap resulteert in een forse verlaging van het economisch rendement per kotter. Onder de omstandigheden van 2016 betekent dit dat het bedrijfsresultaat van een gemiddelde eurokotter 49.000 euro lager is en van een grote kotter 50.000 euro. Echter ook de bemanning levert fors in met 52.000 euro bij een eurokotter tot 68.000 euro voor een grote kotter. Het uiteindelijke resultaat (arbeidsopbrengst) is dan voor een eurokotter iets meer dan 100.000 euro lager en voor een grote kotter bij 120.000 euro.

Ter verklaring van deze uitkomsten moet het volgende nog worden uitgelegd:

De deelloonkosten bedragen gemiddeld circa $40 \%$ van het verschil tussen de besomming, en brandstofkosten en soms nog andere kosten als smeerolie, huur contingent. Het percentage en de kosten die wel of niet worden opgenomen verschilt per schip. Wanneer besomming en brandstofkosten veranderen zullen dus ook de deellonen veranderen.

De deellonen worden in mindering gebracht op het nettoresultaat. Lagere deellonen leiden dus tot relatief lagere kosten op bedrijfsniveau. Als voorbeeld: bij terugkeer naar boomkor zullen de veel hogere brandstofkosten niet worden gecompenseerd door hogere besomming, met andere woorden de deellonen zullen lager uitvallen. Door deze lagere deellonen zullen ook de kosten relatief lager zijn. Het uiteindelijke resultaat wordt bepaald door het totaal van de deellonen en het bedrijfsresultaat. Bij de presentatie van de uitkomsten worden beide kengetallen dan ook weergegeven.

Bij omschakeling naar boomkor is eveneens rekening gehouden met $40 \%$ lagere vistuigkosten. De afschrijvingen van de aanvullende extra investeringen (75.000 euro voor eurokotters en 100.000 euro voor grote kotters) zijn verrekend in het verschil in jaarkosten tussen puls en boomkor. 
Tabel 4.3 Effect van overschakeling van de gemiddelde pulskotter naar de boomkorvisserij. Voor uitgangspunten zie tabel 4.2.

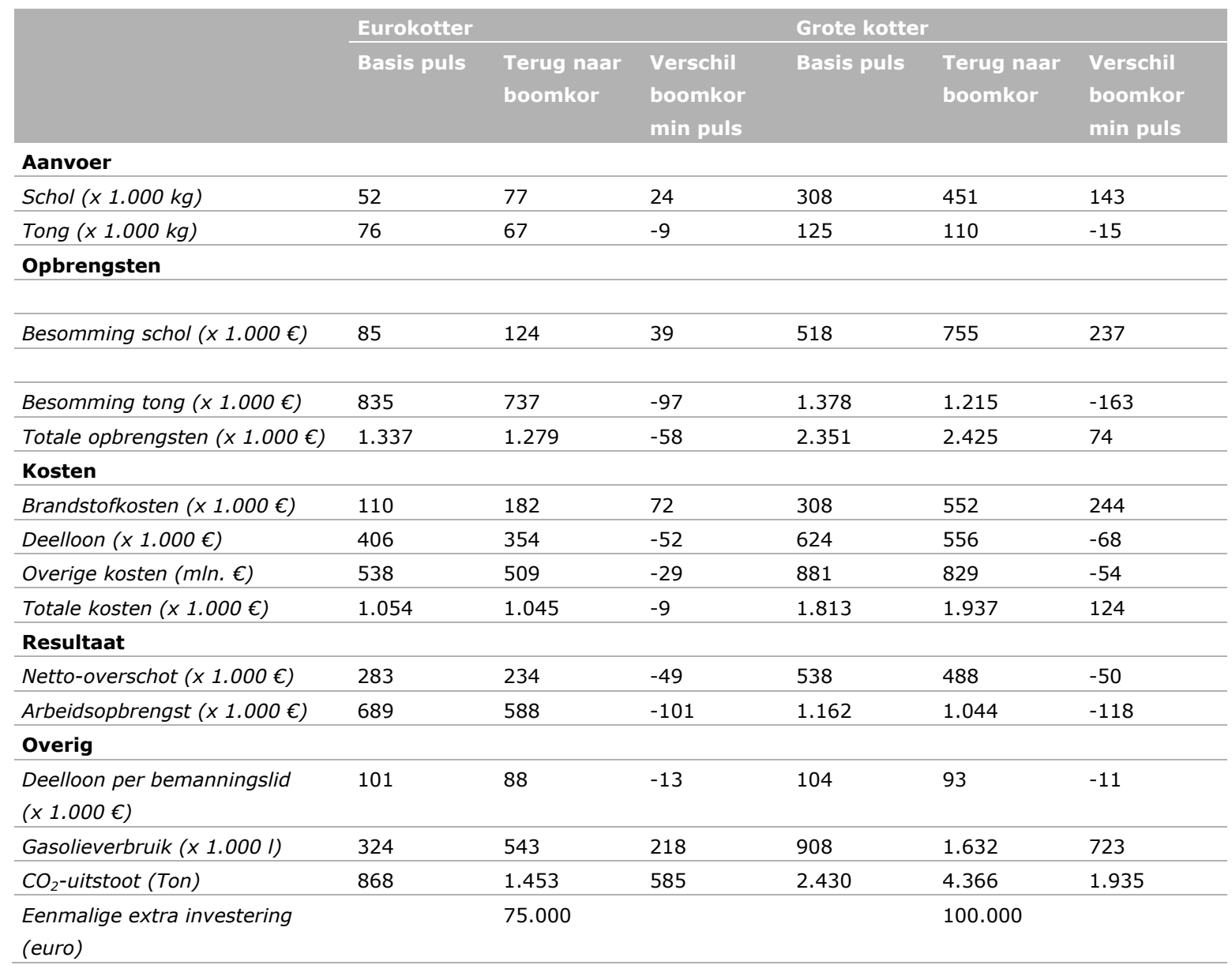

We zien dus dat bij omschakeling naar boomkor het nettoresultaat van eurokotters met 49.000 euro per kotter zal afnemen. Daarnaast nemen echter ook de deellonen af met 52.000 euro per kotter, ofwel 13.000 euro per bemanningslid. In totaal is dit dus een teruggang van ruim 100.000 euro per eurokotter per jaar. Er wordt echter bij deze veronderstelde brandstof- en visprijzen (niveau 2016), ook na omschakeling, nog wel een positief bedrijfsresultaat behaald van 234.000 euro per eurokotter. Door het gestegen brandstofverbruik neemt de $\mathrm{CO}_{2}$-uitstoot per kotter sterk toe met 585 Ton.

Voor de grote kotters neemt het nettoresultaat met 50.000 euro per kotter af, en het totale deelloon met 68.000 euro, ofwel met 11.000 euro per bemanningslid. In totaal is dit een terugval van de arbeidsopbrengst met 118.000 euro, waarbij het nettoresultaat nog uitkomt op 488.000 euro. De $\mathrm{CO}_{2}$ uitstoot per kotter neemt sterk toe met 1.935 ton.

De resultaten voor de totale Nederlandse vloot worden voor deze situatie in tabel 4.4 vermeld. De omschakeling naar de boomkor zal leiden tot een toename van de scholvangsten van 18,3 naar 26,8 miljoen $\mathrm{kg}$. In 2016 was er nog voldoende ruimte in scholquotum om deze toename op te vangen.

Voor tong neemt de vangst met 1 miljoen $\mathrm{kg}$ af van 8,5 naar 7,5 miljoen $\mathrm{kg}$. Het netto-overschot neemt met 3,8 miljoen euro af, en de deellonen met 4,9 miljoen euro, in totaal dus een afname van de arbeidsopbrengst met 8,7 miljoen euro. 
Tabel 4.4 Economisch resultaat en $\mathrm{CO}_{2}$-uitstoot van het total van de pulskotters van de Nederlandse vloot: situatie met puls 2016 en situatie bij omschakeling naar boomkor (2016)

\begin{tabular}{|c|c|c|c|}
\hline & \multicolumn{3}{|l|}{ NL Vloot } \\
\hline & Basis puls & Terug naar boomkor & Verschil boomkor min puls \\
\hline \multicolumn{4}{|l|}{ Aanvoer } \\
\hline Schol (m/n. kg) & 18,3 & 26,8 & 8,5 \\
\hline Tong (m/n. kg) & 8,5 & 7,5 & 1,0 \\
\hline \multicolumn{4}{|l|}{ Opbrengsten } \\
\hline Besomming schol (m/n. €) & 30,7 & 44,8 & 14,1 \\
\hline Besomming tong (m/n. $€$ ) & 93,9 & 82,8 & $-11,1$ \\
\hline Totale opbrengsten (m/n. €) & 158,4 & 161,4 & 3,0 \\
\hline \multicolumn{4}{|l|}{ Kosten } \\
\hline Brandstofkosten (m/n. $€$ ) & 19,4 & 34,6 & 15,2 \\
\hline Deelloon (m/n. $€$ ) & 43,1 & 38,2 & $-4,9$ \\
\hline $\begin{array}{l}\text { Overige kosten } \\
(m / n . €)\end{array}$ & 60,1 & 56,6 & $-3,4$ \\
\hline Totale kosten $(x(m / n . €)$ & 122,6 & 129,4 & 6,8 \\
\hline \multicolumn{4}{|l|}{ Resultaat } \\
\hline Netto-overschot (m/n. $€$ ) & 35,8 & 32,0 & $-3,8$ \\
\hline Arbeidsopbrengst (m/n. €) & 78,9 & 70,2 & $-8,7$ \\
\hline \multicolumn{4}{|l|}{ Overig } \\
\hline Gasolieverbruik (x mln I) & 57,4 & 102,2 & 44,9 \\
\hline $\mathrm{CO}_{2}$-uitstoot (kTon) & 153 & 274 & 120 \\
\hline
\end{tabular}

\subsection{Resultaten bij verschillende prijsniveaus voor vis en brandstof}

Bij de voorgaande berekeningen is uitgegaan van de prijsniveaus van het jaar 2016. Tabel 4.5 geeft de prijzen weer voor het jaar 2017, met een hogere scholprijs, een lagere tongprijs en een hogere brandstofprijs. Tabel 4.6 geeft de resultaten van de omschakeling weer voor het jaar 2017.

Tabel 4.5 Prijzen in de jaren 2016 en 2017 ( $€$ per liter brandstof of per $\mathrm{kg}$ vis)

\begin{tabular}{lll} 
& 2016 & 2017 \\
Gem. brandstofprijs & 0,34 & 0,39 \\
\hline Gem. schol prijs & 1,65 & 1,87 \\
\hline Gem. tong prijs & 11,05 & 10,80 \\
\hline
\end{tabular}

Tabel 4.6 Economisch resultaat per kotter en van het totaal van de pulskotters van de Nederlandse vloot: situatie met pulsen prijsniveau 2017 en situatie bij overschakeling naar boomkor (2017)

\begin{tabular}{|c|c|c|c|c|c|c|c|}
\hline & Puls 2017 & & $\begin{array}{l}2017 \text { terug } \\
\text { boomkor }\end{array}$ & naar & Puls 2017 & $\begin{array}{l}2017 \text { terug } \\
\text { naar boomkor }\end{array}$ & Verschil \\
\hline & Eurokotter & Grote kotter & Eurokotter & Grote kotter & Totaal NL & Totaal NL & Totaal NL \\
\hline $\begin{array}{l}\text { Totaal deelloon } \\
\text { (x } 10.000 \text { euro) }\end{array}$ & 398 & 624 & 344 & 555 & 42.900 & 38.000 & -4.900 \\
\hline
\end{tabular}


Het netto-overschot is zowel in de basis situatie (met pulsvisserij) als in de omschakelingssituatie in 2017 ten opzichte van 2016 bij deze prijzen iets lager. Het totale 'verlies' als gevolg van de omschakeling van puls naar boomkor is even groot als bij de prijsverhoudingen van het jaar 2016, namelijk -3,8 miljoen euro voor het netto-overschot, $-4,9$ miljoen euro voor het deelloon en $-8,7$ miljoen euro totaal per jaar.

\subsection{Gevoeligheidsanalyse voor prijsverschillen}

Om meer inzicht te verkrijgen in de gevolgen van omschakeling is een gevoeligheidsanalyse uitgevoerd bij 4 mogelijke prijssituaties. Deze 4 zijn in onderstaand schema weergegeven:

\begin{tabular}{lll} 
& Hoge visprijzen & Lage visprijzen \\
Lage brandstofprijzen & A & C \\
\hline Hoge brandstofprijzen & B & D \\
\hline
\end{tabular}

Voor de keuze van de hoogte van de brandstofprijs en de visprijzen, en daarmee voor de scenario's, kijken we allereerst naar het verloop van deze prijzen vanaf 1990.

Figuur 4.1 geeft de ontwikkeling van de gasolieprijs weer. In 2016 bedroeg de prijs 0,34 euro per liter, in 2017 0,39 cent. In het jaar 2012 was de prijs 0,66 euro per liter. Verwacht kan worden dat de olieprijs niet meer het lage niveau van voorheen zal bereiken. Voor de scenario's zijn we uitgegaan van een gasolieprijs van 0,40 cent voor het gunstige scenario, en 0,60 euro voor het ongunstige scenario.

0,80

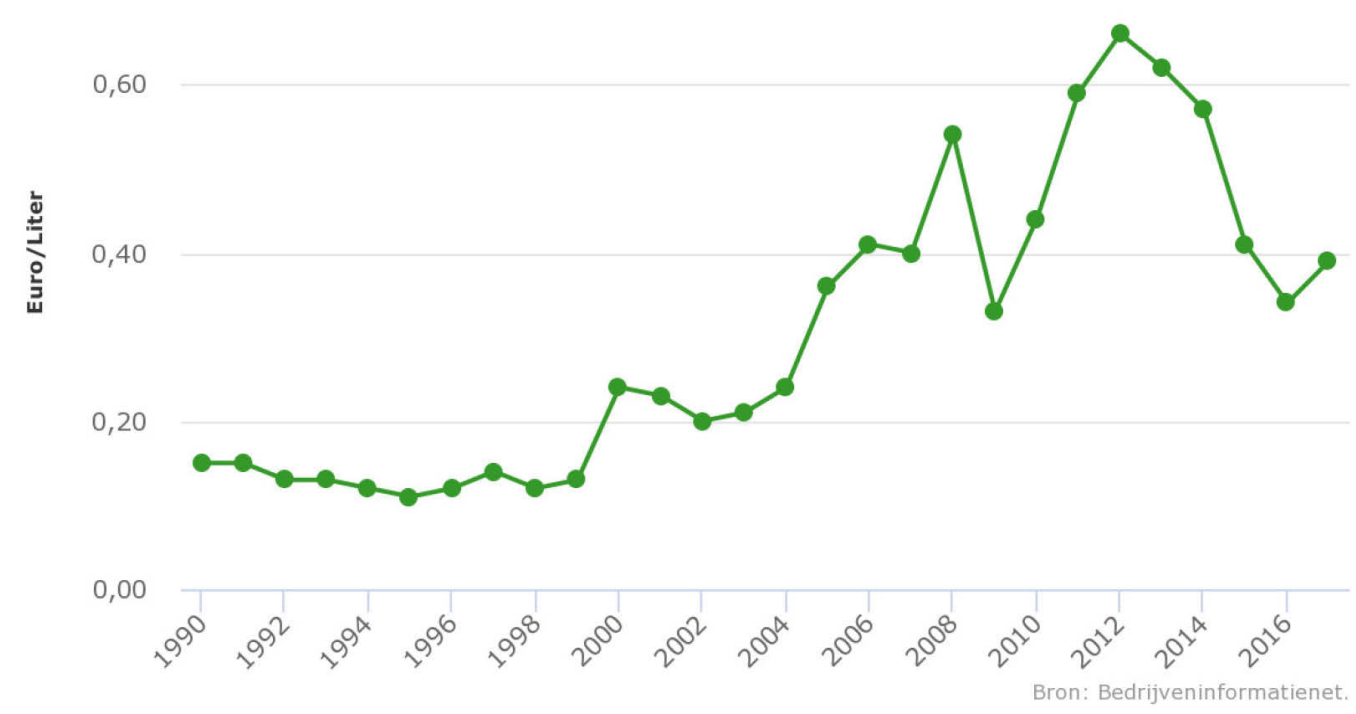

Figuur 4.1 Gemiddelde gasolieprijs kottervisserij 1990 tot 2017

Figuur 4.2 geeft de prijzen van tong en schol vanaf 2003 weer. Voor tong schommelde de prijs tussen 8,22 en 12,92 euro per $\mathrm{kg}$. Hierbij is gekozen voor prijsniveau laag 9,00 euro en prijsniveau hoog 12,00 euro per $\mathrm{kg}$.

De prijs van schol varieerde tussen 2003 en 2017 tussen 1,24 euro en 2,08. De laatste jaren is de prijs van schol stijgende. Voor de scholprijs wordt uitgegaan van 1,30 euro voor het lage prijsscenario en 2,00 euro voor het hoge prijsscenario. De prijzen van de overige vis (overige vis maakt nog zo'n $20 \%$ van de totale besomming uit) laten we hier buiten beschouwing. 

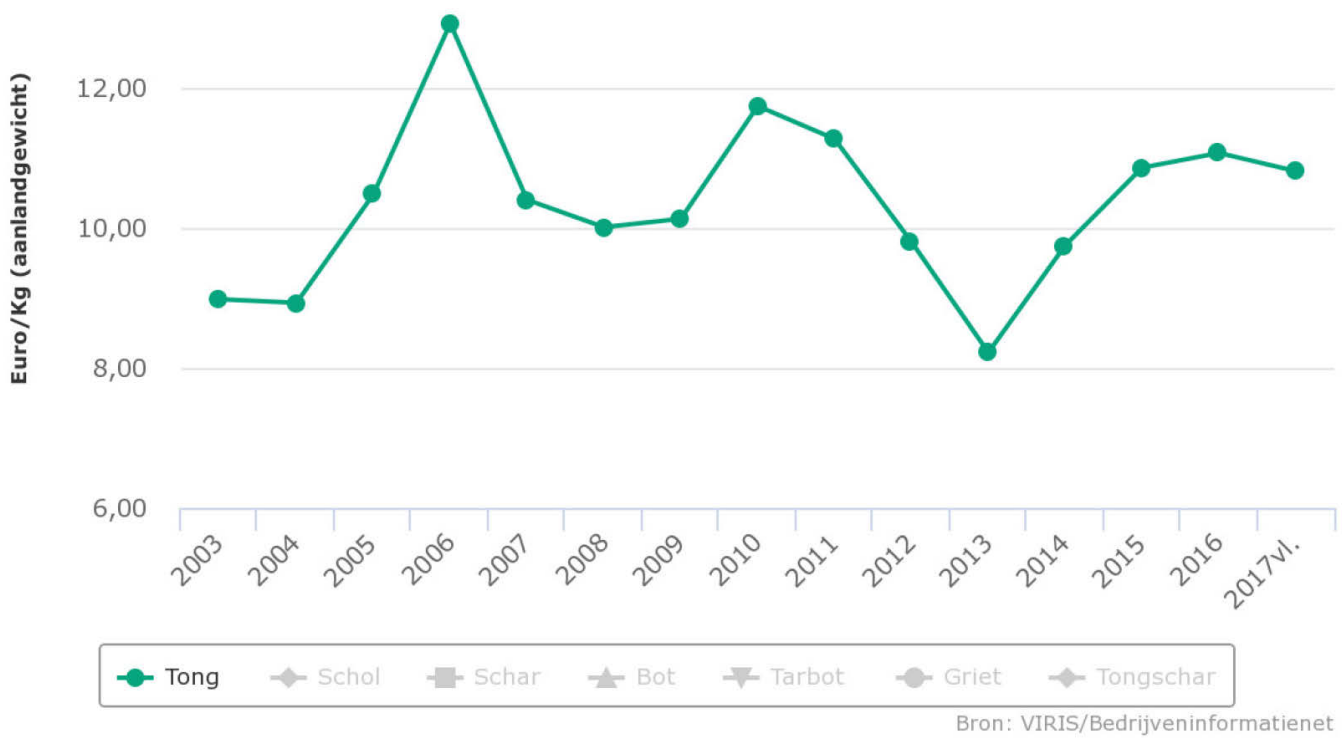

Figuur 4.2a Prijsontwikkeling tong

2,25
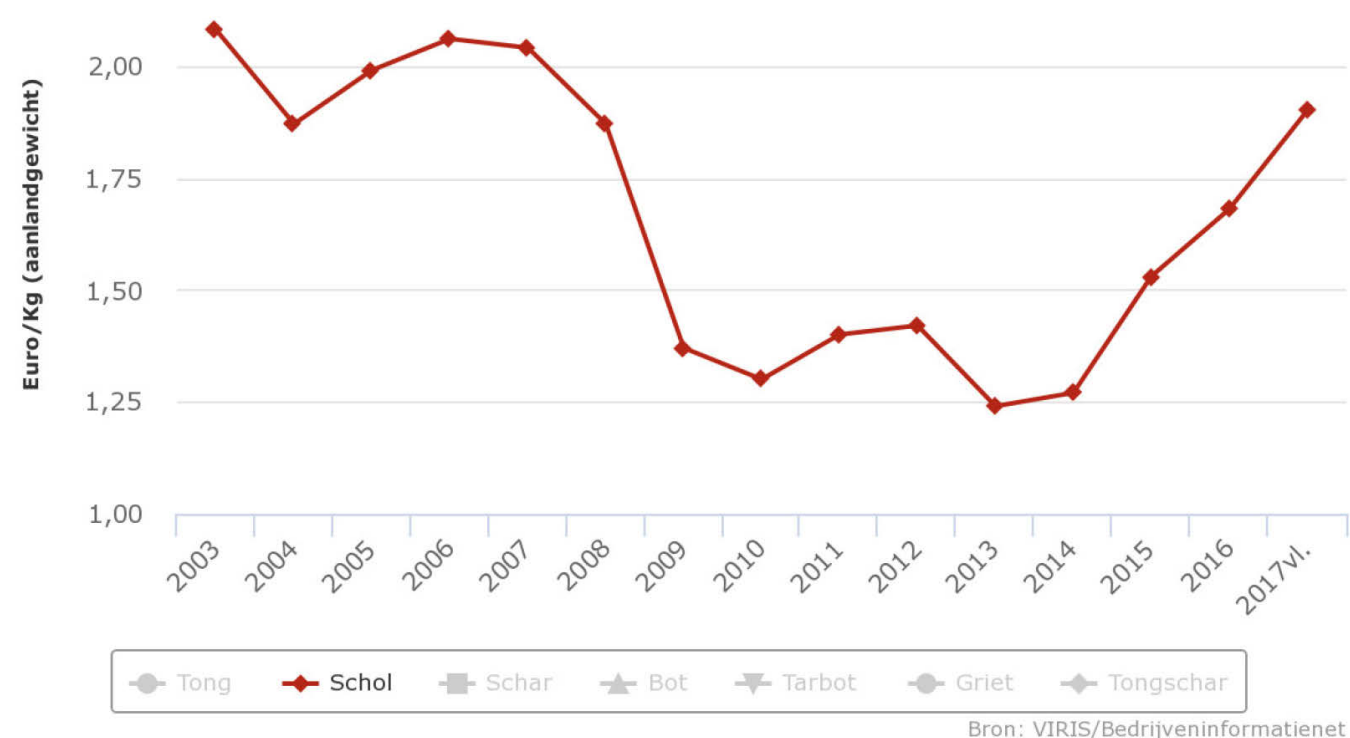

Figuur 4.2b Prijsontwikkeling schol

Samengevat komen we dan tot de volgende uitgangspunten voor de prijsgevoeligheidsanalyse:

\begin{tabular}{lllll} 
Scenario & Omschrijving & Scholprijs in $\mathrm{C} / \mathrm{kg}$ & Tongprijs in $\mathrm{C} / \mathrm{kg}$ & Olieprijs in $\mathrm{C/I}$ \\
$\mathrm{A}$ & Hoge visprijzen, lage brandstofprijs & 2,00 & 12,00 & 0,40 \\
\hline B & Hoge visprijzen, hoge brandstofprijs & 2,00 & 12,00 & 0,60 \\
\hline C & Lage visprijzen, lage brandstofprijs & 1,30 & 9,00 & 0,40 \\
\hline D & Lage visprijzen, hoge brandstofprijs & 1,30 & 9,00 & 0,60 \\
\hline
\end{tabular}

Tabel 4.7 geeft een samenvatting van de arbeidsopbrengst per kotter. In de bijlage staan de gedetailleerde resultaten van de kottersegmenten vermeld. Zoals hiervoor is aangegeven is de arbeidsopbrengst het totaal van nettoresultaat en deelloon. 
Tabel 4.7

Arbeidsopbrengst (euro) per kotter

\begin{tabular}{lllll} 
& \multicolumn{2}{l}{ Eurokotter } & & Grote kotter \\
\cline { 2 - 5 } Scenario & Na omschakeling & Verschil ten opzichte & Na omschakeling & Verschil ten opzichte \\
naar boomkor & van puls & nal boomkor & -127.000 \\
\hline B & 649.000 & -115.000 & 1.217 .000 & -274.000 \\
\hline C & 539.000 & -159.000 & 886.000 & -184.000 \\
\hline D & 394.000 & -105.000 & 562.000 & -330.000 \\
\hline
\end{tabular}

Logischerwijs nemen de arbeidsopbrengsten af naarmate de prijsscenario's ongunstiger zijn. Te zien is ook dat de grote kotters gevoeliger zijn voor de ongunstige prijsscenario's dan de eurokotters. $\mathrm{Er}$ is echter een grote spreiding in de individuele resultaten van bedrijven. In het jaar 2016 behaalde geen van de kotters een negatief nettoresultaat. Bij het ongunstige prijsscenario is de situatie echter compleet anders. Figuur 4.3 geeft een overzicht van de spreiding van de berekende nettoresultaten per kotter bij het ongunstige prijsscenario (D) in de uitgangssituatie (dus met pulsvisserij), en na omschakeling naar boomkor. Voor omschakeling heeft bijna 15\% van de bedrijven een negatief nettoresultaat, na omschakeling neemt dit percentage toe naar $43 \%$.

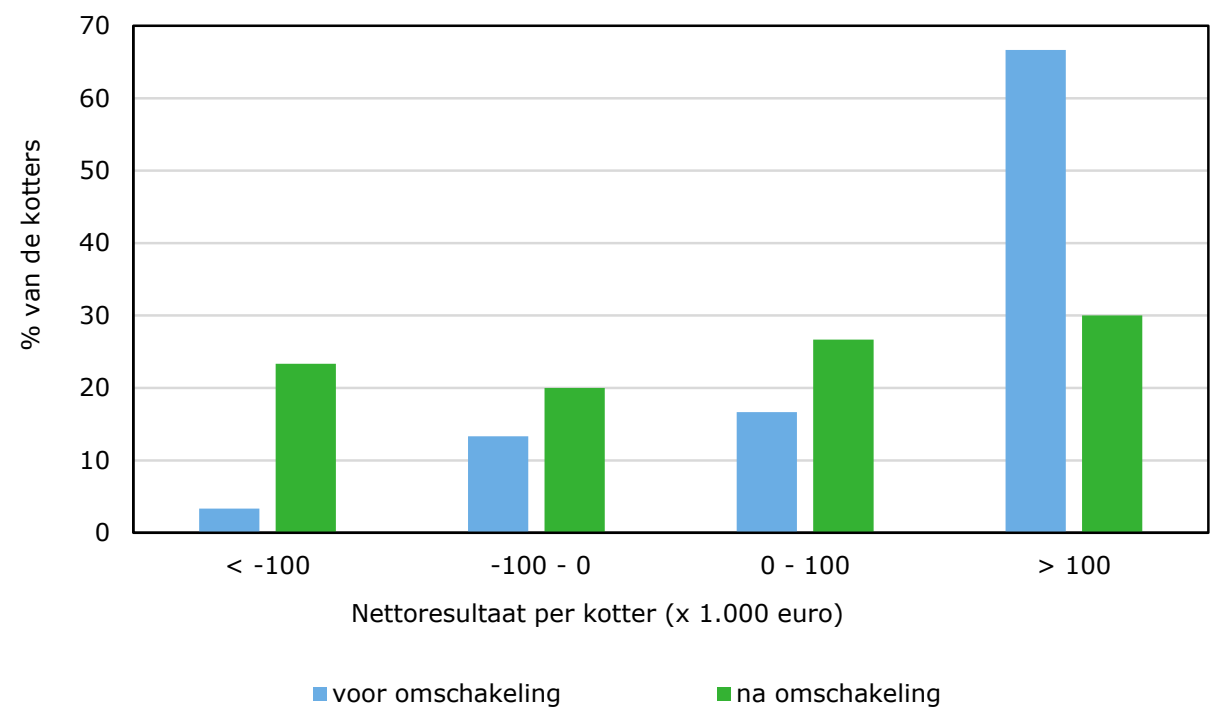

Figuur 4.3 Spreiding van berekend nettoresultaat per kotter voor en na omschakeling van puls naar boomkor bij het ongunstige prijsscenario

De resultaten van totaal Nederland bij de verschillende prijsscenario's worden hierna weergegeven.

Tabel 4.8 Economische effecten van omschakeling van de pulskorkotters naar de boomkorvisserij bij hoge visprijzen en lage brandstofprijzen (scenario A) voor de hele Nederlandse visserij

\begin{tabular}{llll}
$\begin{array}{l}\text { Hoge visprijzen, lage brandstofprijs (A) } \\
\text { a) }\end{array}$ & $\begin{array}{l}\text { Met pulsvisserij } \\
\text { Totale opbrengsten (x mln. euro) }\end{array}$ & $\begin{array}{l}\text { Na omschakeling naar } \\
\text { boomkor }\end{array}$ & Verschil \\
\hline Technische kosten (x mln. euro) & 873,7 & 178,6 & 4,9 \\
\hline Totaal deelloon (x mln. euro) & 47,7 & 97,5 & 14,3 \\
\hline Netto-overschot (x mln. euro) & 42,8 & 42,6 & $-5,1$ \\
\hline Totaal arbeidsopbrengst (x mln. euro) & 90,5 & 38,5 & $-4,3$ \\
\hline
\end{tabular}

a) Schol: $€ 2,00 / \mathrm{kg}$; Tong: $€ 12,00 / \mathrm{kg}$; Olie: $€ 0,40 / \mathrm{l}$. 
Tabel 4.8 geeft de resultaten voor het gunstige prijsscenario (A). Bij omschakeling neemt de totale besomming toe, vooral doordat de lagere tongvangsten worden gecompenseerd door de veel hogere scholvangsten, maar de kosten nemen vooral door de hogere brandstofkosten sterk toe, waardoor het netto-overschot met 4,3 miljoen euro afneemt. De deellonen nemen met 5,1 miljoen euro af waardoor bij omschakeling van de pulsvisserij naar boomkor het resultaat van de pulsvloot afneemt met 9,4 miljoen.

Tabel 4.9 Economische effecten van omschakeling van de pulskorkotters naar de boomkor visserij bij hoge visprijzen en hoge brandstofprijzen (scenario B) voor de hele Nederlandse visserij

\begin{tabular}{llll} 
Hoge visprijzen, hoge brandstofprijs (B) a) & Met pulsvisserij & Na omschakeling naar boomkor Verschil & Vo \\
Totale opbrengsten (x mln. euro) & 173.700 & 178.600 & 23.900 \\
\hline Technische kosten (x mln. euro) & 94.800 & 118.200 & -8.800 \\
\hline Totaal deelloon (x mln. euro) & 43.100 & 34.300 & -9.700 \\
\hline Netto-overschot (x mln. euro) & 35.800 & 26.100 & -18.500 \\
\hline Totaal arbeidsopbrengst (x mln. euro) & 78.900 & 60.400 & \\
\hline
\end{tabular}

a) Schol: $€ 2,00 / \mathrm{kg}$; Tong: $€ 12,00 / \mathrm{kg}$; Olie: $€ 0,60 / \mathrm{l}$.

Tabel 4.9 geeft de resultaten voor het scenario met hoge visprijzen en hoge brandstofprijs. De hoge olieprijs heeft een negatief effect op het nettoresultaat in de uitgangssituatie (met puls), omdat de olie kosten fors hoger zijn. Het verschil tussen puls en boomkor wordt hierdoor ook fors hoger, namelijk 9,7 miljoen euro als gevolg dat de hogere brandstofprijs sterk doortelt in de uiteindelijke brandstofkosten. Door de hogere brandstofkosten worden zowel de arbeidsopbrengst, als het totale deelloon fors lager; respectievelijk 18,5 miljoen euro en 8,8 miljoen euro. Het uiteindelijke nettooverschot blijft in deze situatie echter ook positief.

Tabel 4.10 Economische effecten van omschakeling van de pulskorkotters naar de boomkorvisserij bij lage visprijzen en lage brandstofprijzen (scenario C) voor de hele Nederlandse visserij

\begin{tabular}{llll} 
Lage visprijzen, lage brandstofprijs (C) a) & Met pulsvisserij & Na omschakeling naar boomkor Verschil \\
Totale opbrengsten (x mln. euro) & 135,0 & 137,0 & 2,0 \\
\hline Technische kosten (x mln. euro) & 83,3 & 97.6 & 14,3 \\
\hline Totaal deelloon (x mln. euro) & 32,2 & 25,9 & $-6,3$ \\
\hline Netto-overschot (x mln. euro) & 19,5 & 13,5 & $-6,0$ \\
\hline Totaal arbeidsopbrengst (x mln. euro) & 51,7 & 39,4 & $-12,3$ \\
\hline
\end{tabular}

a) Schol: $€ 1,30 / \mathrm{kg}$; Tong: $€ 9,00 / \mathrm{kg}$; Olie: $€ 0,40 / \mathrm{l}$.

In het scenario met lage visprijzen en een lage brandstofprijs daalt het netto-overschot daalt met 6,0 miljoen euro. De totale arbeidsopbrengst daalt met 12,3 miljoen euro. De hogere brandstofprijs zorgt dus voor een grotere daling van het resultaat dan lagere visprijzen.

Tabel 4.11 Economische effecten van omschakeling van de pulskorkotters naar de boomkor visserij bij lage visprijzen en hoge brandstofprijzen (scenario D) voor de hele Nederlandse visserij

\begin{tabular}{llll} 
Lage visprijzen, hoge brandstofprijs (D) a) & Met pulsvisserij & Na omschakeling naar boomkor Verschil & Vo \\
\hline Totale opbrengsten (x mln. euro) & 135,0 & 137,0 & 2,0 \\
\hline Technische kosten (x mln. euro) & 94,4 & 118,4 & 23,5 \\
\hline Totaal deelloon (x mln. euro) & 27,6 & 17,6 & $-10,0$ \\
\hline Netto-overschot (x mln. euro) & 12,5 & 1,0 & $-11,5$ \\
\hline Totaal arbeidsopbrengst (x mln. euro) & 40,1 & 18,6 & $-21,5$ \\
\hline
\end{tabular}

a) Schol: $€ 1,30 / \mathrm{kg}$; Tong: $€ 9,00 / \mathrm{kg}$; Olie: $€ 0,60 / \mathrm{l}$. 
Tabel 4.11 is het meest ongunstige, maar niet ondenkbare scenario. Deze situatie heeft zich in de jaren 2012-2014 voorgedaan. In dit scenario is het nettoresultaat in de uitganssituatie flink lager dan in de andere scenario's; 12,5 mln. euro. Lage visprijzen en hoge brandstofprijzen zorgen voor een daling van het netto-overschot van 11,5 miljoen euro, en het totaal aan deellonen dalen met 10,0 miljoen euro zodat de totale arbeidsopbrengst met 21,5 miljoen euro daalt bij de omschakeling van puls naar boomkor. Het netto-overschot zelf daalt tot dichtbij het break-evenniveau. Uit bijlage 1 blijkt dat het gemiddelde netto-overschot bij de omschakeling naar boomkor bij deze prijzen voor eurokotters gemiddeld 52.000 euro bedraagt maar voor de grote kotters nog geen 1.000 euro. Daar komt dan ook bij dat de deellonen (inclusief te betalen sociale premies) per bemanningslid sterk gedaald zijn tot 58.000 voor een eurokotter en 39.000 euro voor een grote kotter. 


\section{$5 \quad$ Overige effecten en discussie}

In hoofdstuk 4 zijn de resultaten van modelberekeningen beschreven, waarbij als uitgangspunt is genomen de verandering in bedrijfsresultaat op kotterniveau op korte termijn. Er zijn echter ook andere aspecten die een rol zullen spelen bij een mogelijk pulsverbod, en die invloed hebben op het sociaal-economisch functioneren van de sector na dit verbod. Deze aspecten worden hier kort toegelicht.

\subsection{Overige effecten voor de visserijsector}

\subsubsection{Financiële positie van bedrijven}

In figuur 4.3 hebben we de spreiding van de individuele bedrijfsresultaten gezien. Daarnaast is echter ook de financiële positie van bedrijven verschillend.

De winstgevendheid van de sector is de afgelopen jaren heel goed geweest maar in een periode daarvoor slechts gering of zelfs negatief (figuur 5.1).

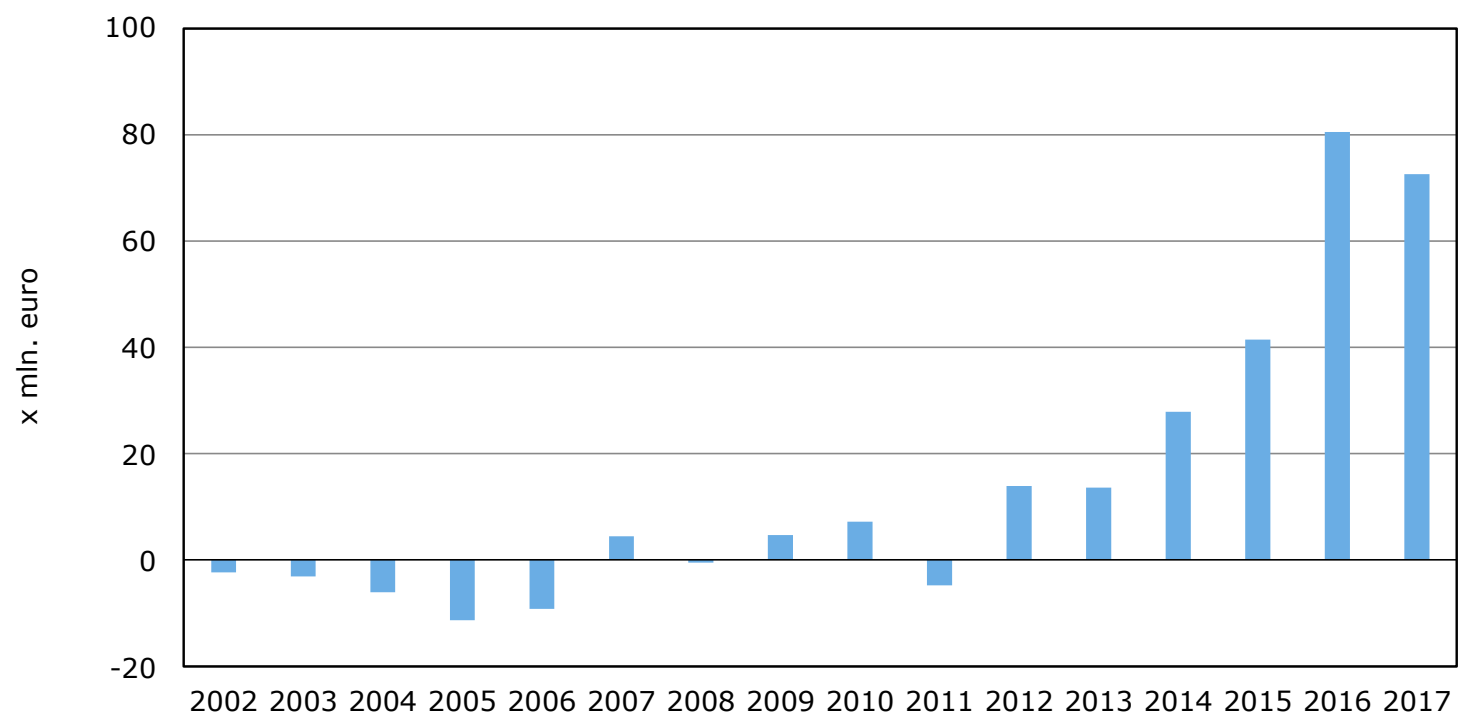

Figuur 5.1 Nettoresultaat Nederlandse kottersector periode 2002 tot en met 2017 Bron: Visserij in cijfers (www. visserijincijfers. $n l$ ).

Figuur 5.1 geeft het resultaat weer van de totale Nederlandse kotter sector, dus ook inclusief de pulskotters. De figuur laat zien dat in het jaar 2012 een kentering is ontstaan in het resultaat, mede dankzij de inzet van pulsvisserij, na een 10-jarige periode met soms positieve maar meer negatieve nettoresultaten (www.visserijincijfers.nl). Het zal dan ook duidelijk zijn dat een groot aantal bedrijven met grote verliezen te maken had, en daarmee aan de rand van een faillissement stonden. Voor deze bedrijven zal het een lange periode duren voordat de opgelopen verliezen gecompenseerd kunnen worden. In die periode werden bedrijven veelal met familiekapitaal en coulance van de banken operationeel gehouden.

Toen de eerste 42 pulsontheffingen werden verstrekt in 2011 was er een beperkt aantal bedrijven (42) die daar gebruik van kon maken. Deze bedrijven werden veelal gesteund door banken om te 
kunnen investeren in het pulstuig (telefonische interviews). Dankzij de goede resultaten van de pulsvisserij hebben deze bedrijven hun opgelopen achterstand en verlies grotendeels kunnen inhalen. Bij het verstrekken van laatste 42 pulsontheffingen in 2014 bevonden de bedrijven die hier nog gebruik van konden maken zich in een achterstandspositie ten opzichte van de eerste groep - ze hadden immers nog drie jaren langer geen winst kunnen maken. Het is aannemelijk dat met name deze laatste bedrijven een lagere solvabiliteit hebben, en mogelijk bij het intrekken van de vergunningen als eerste in een financieel moeilijke positie terechtkomen.

\subsubsection{Deelloon bemanning}

Bij teruglopende besommingen en toenemende brandstofkosten zullen de deellonen lager uitvallen. In het jaar 2016 bedroeg het deelloon per bemanningslid iets meer dan 100.000 euro (inclusief de af te dragen sociale lasten). Uit de interviews is gebleken dat veel schippers zijn overgegaan tot het aantrekken van één bemanningslid extra om het werk aan boord te verlichten, of om de gelegenheid te bieden een week extra aan wal te blijven. Wanneer het deelloon echter terug zal lopen zal dit consequenties hebben voor de (financiële) aantrekkelijkheid voor bemanning en het beperken van het aantal bemanningsleden per kotter. In het meest onaantrekkelijke scenario gaat het deelloon per opvarende door een verandering van prijzen en de omschakeling naar de boomkor naar 58.000 euro voor een eurokotter en 39.00 euro voor een grote kotter. Hierdoor zal het moeilijker worden om gekwalificeerd personeel aan te trekken met alle gevolgen van dien. Daar komt bij dat als gevolg van de omschakeling er een verschuiving van de vangst komt van minder tong naar veel meer schol, waarmee het (strip)werk aan boord toeneemt en daarmee tevens de arbeidsdruk.

\subsubsection{Investeringen, desinvesteringen, onderhoud en nieuwbouw}

De omschakeling naar boomkor zal in eerste instantie zorgen voor een toenemende vraag naar boomkortuigen, die door de toeleverende bedrijven worden aangeleverd. Zoals hiervoor is weergegeven betreft het een investering van 75.000 euro voor een eurokotter tot 100.000 euro voor een grote kotter. Dit bedrag heeft niet elk bedrijf op de plank liggen zal in een aantal gevallen moeten worden gefinancierd. Een schatting vanuit de telefonische interviews is dat driekwart van de visserijbedrijven die momenteel met pulstuigen vissen nieuw moeten investeren in de boomkor.

$\mathrm{Er}$ is ook een kapitaalverlies doordat de pulstuigen niet meer gebruikt kunnen worden en ook niet kunnen worden verkocht. Deze investeringen bedragen 250.000 euro voor een eurokotter en 350.000 euro voor een grote kotter. Bij de 76 kotters is daarmee een totaalbedrag van circa 25 miljoen euro gemoeid. Gemiddeld genomen is de afschrijving op de pulstuigen ongeveer 5 jaar. Pulsmodules en pulskabels kennen echter een kortere levensduur. De pulstuigen die inmiddels zijn aangeschaft zijn dus onderhand ook weer afgeschreven, en mogelijk weer vervangen. Bij een pulsverbod zal er mogelijk kapitaalverlies zijn maar het is niet in te schatten hoe hoog dit verlies zal zijn.

Tegenover de lagere onderhoudskosten voor vistuig staan bij overschakeling naar de boomkor waarschijnlijk hogere onderhoudskosten voor de motor. Voor pulsvisserij is minder trekkracht benodigd, worden motoren dus minder zwaar belast en is er minder onderhoud verricht want noodzakelijk onderhoud van motoren kon hierdoor naar achteren worden geschoven. Het opnieuw toepassen van de boomkor betekent dat de motoren op volle kracht zullen moeten draaien met hogere onderhoudskosten van dien. Uit de telefonische interviews met motorenleveranciers komt naar voren dat de onderhoudskosten evenredig zullen toenemen met de kilowatturen die nodig zijn. Deze extra kosten zijn niet meegenomen in de berekeningen.

Sinds het jaar 2012 is er een toename van investeringen in de sector, vooral in vistuigen en casco aanpassingen (www.visserijincijfers. $\mathrm{nl}$ ). In het jaar 2017 is in de totale visserijsector circa 20 miljoen geïnvesteerd. In 2017 maar ook 2018 zullen verschillende nieuwbouwkotters in de vaart komen. Het merendeel van de kotters (75\%) is echter ouder dan 20 jaar en nieuwbouw is noodzakelijk voor meer efficiëntie, zuiniger motoren en dergelijke. Bij een terugval van het economisch resultaat zal de noodzakelijke vernieuwingsslag van de vloot trager verlopen, of in het meest ongunstige geval niet meer kunnen plaatsvinden, met alle gevolgen ook voor de scheepswerven en toeleverende industrie. 
Bij het meest ongunstige scenario is de rentabiliteit van een groot deel van de bedrijven negatief en dus zijn de continuïteitsperspectieven slecht. Dit kan leiden tot faillissementen en/of opkoop door grotere rederijen.

\subsubsection{Handelingsruimte voor vissers, vangstsamenstelling en quotum}

Eurokotters zijn flexibeler in de keuze voor bepaalde typen visserij dan de grote kotters. Er zijn eurokotters die ook op garnalen vissen, twinriggen of met borden vissen. Door het intrekken van de pulsontheffingen kunnen deze kotters eventueel langer doorvissen op de alternatieve visserij in het geval dit economisch rendabeler is, om te proberen het (negatieve) effect van omschakeling naar de boomkor zoveel mogelijk te verminderen. Hier is in de berekeningen geen rekening mee gehouden.

Pulsvisserij is een typische tongvisserij. Uitgaande van de historische vangstsamenstelling van de boomkorvisserij zal bij stopzetting dus minder tong worden gevangen en meer schol. In 2017 is er ook nog veel ruimte voor extra schol, de scholquota zijn de laatste jaren niet volledig benut. In de praktijk kan het zijn dat vissers toch zullen proberen de visgebieden zodanig te verschuiven dat er relatief meer op de duurdere tong gevist gaat worden en minder op schol om zo de besomming te verhogen. Overigens wordt er op dit moment bericht (april 2018) dat ondanks de goede bestanden voor schol, de vangbaarheid van schol slecht is en daarmee de aanvoer laag. Omgekeerd heeft dit een prijsopdrijvend effect waar vooral de handel en verwerking mee te maken krijgt. Daarnaast kan het zijn dat door een meervangst van schol de prijzen zullen dalen en dat mogelijk door een mindere vangst van tong de prijzen zullen stijgen. In de berekeningen is hier geen rekening mee gehouden.

Door de lagere aanvoer van tong zal ook de vraag naar tongquotum afnemen, en dit zal effect hebben op de huurprijzen van tong. In het verleden zagen we dat de vraag naar tongquotum is toegenomen, mogelijk door de pulsvisserij, en daarmee de prijs van tongquotum. Een lagere quotumprijs gaat voor een aantal bedrijven gepaard met lagere quotumkosten terwijl het voor andere bedrijven minder inkomsten zal betekenen. De quotumprijs is begin 2017 al sterk gedaald, waarschijnlijk als gevolg van de verhoging van het tongquotum (zie figuur 5.2). De huurprijs van scholquotum zal wellicht minder beïnvloed worden doordat er anno 2018 een ruim scholquotum is. De totale effecten van deze prijsveranderingen zijn moeilijk in te schatten en in de berekeningen is dan ook geen rekening gehouden met een verandering van de quotumprijs.

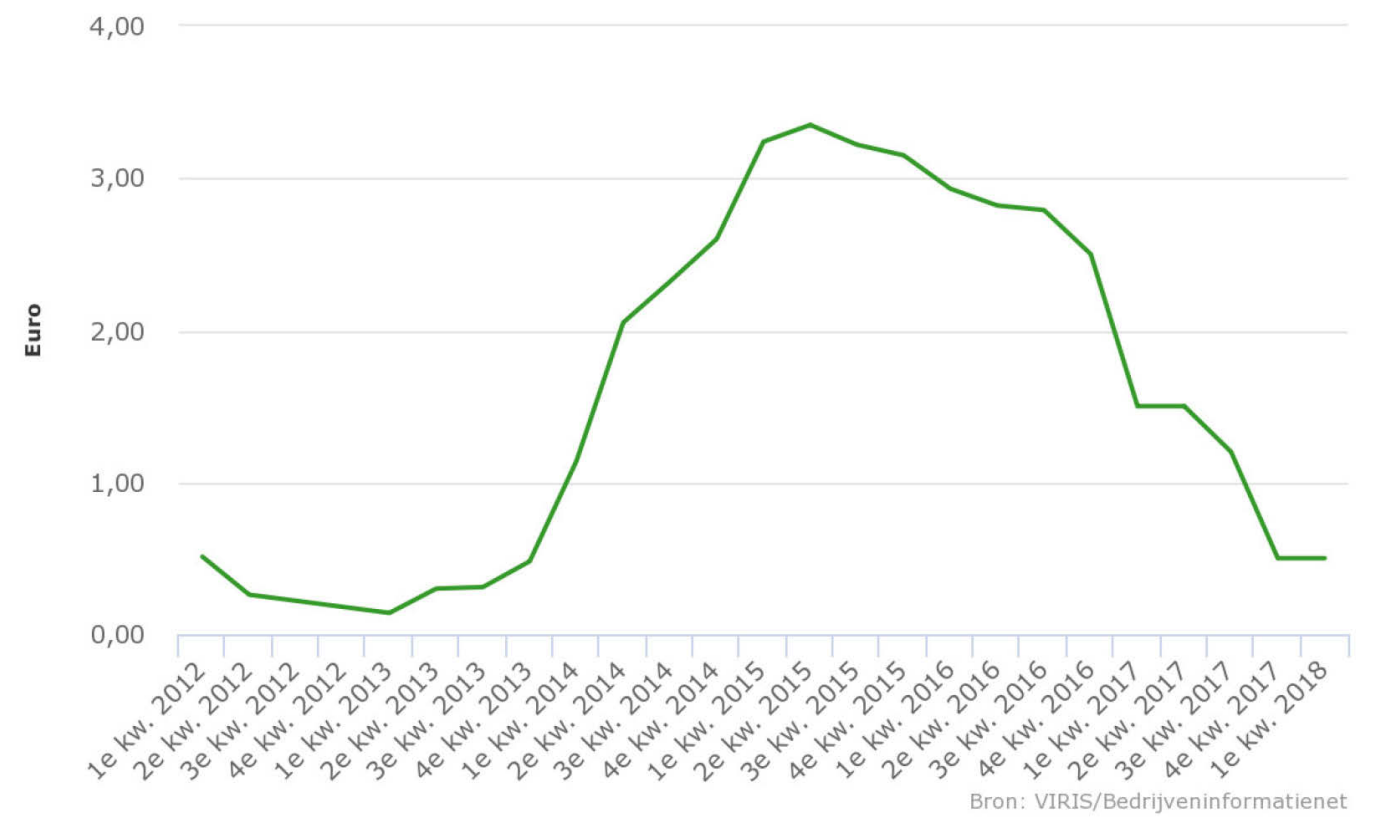

Figuur 5.2 Verloop huurprijs van tongquotum 


\subsection{Indirecte effecten op toelevering en verwerking}

De overstap van de pulsvisserij naar de boomkorvisserij zal niet alleen gevolgen hebben voor de visserijbedrijven zelf, maar ook voor de toeleverende industrie (bijvoorbeeld scheeps- en werfbouw, elektrobedrijven, timmerbedrijven enzovoort), havenbedrijven (bijvoorbeeld service in de haven), visafslagen (wegen, sorteren en distribueren van aangelande vis), verwerkings- en handelsbedrijven (verwerken, verpakken en/of verhandelen van de vis) en transportbedrijven (nationaal of internationaal transport van vis). Er zullen duidelijk effecten zijn die gevolgen hebben voor andere schakels in de keten zoals:

- minder tong aanvoer,

- meer scholaanvoer,

- minder onderhoud aan tuigen,

- investeringen in boomkortuigen,

- meer onderhoud motoren,

- minder marge in de visserij,

- lagere deellonen.

De veranderende aanvoer van tong en schol zal duidelijk invloed hebben op de handel en verwerking in de grotere visclusters. Tong bedient meer de versmarkt. Schol bevindt zich meer in de witvismarkt waar substitutie kan plaatsvinden met andere vissoorten. Wat dit concreet betekent voor de visverwerkende bedrijven is moeilijk aan te geven.

De omschakeling naar boomkor betekent minder onderhoud en onderhoudskosten voor de visserij bedrijven. Het wegvallen van de hogere onderhoudskosten van pulstuigen is enerzijds een meevaller voor de visserijbedrijven, maar anderzijds een tegenvaller voor de leveranciers, die hierdoor minder werkgelegenheid zullen hebben.

Ten slotte zal het achterstallige onderhoud dat aan motoren verricht moet worden door scheepswerven die hierdoor extra omzet zullen draaien. De kosten hiervan komen ten laste van de visserij ondernemers.

De lagere deellonen zullen grote consequenties hebben. Veel gezinnen zijn hiervan afhankelijk, en zij zullen minder te besteden hebben. Worden de deellonen te laag dan zullen de bemanningsleden geneigd zijn om andere inkomstenbronnen te gaan zoeken, en het zal dan moeilijk zijn om andere goed gekwalificeerde bemanningsleden te vinden.

Een verdere duiding van deze kwantitatieve gegevens is niet beschikbaar voor dit onderzoek. Echter, uit de interviews met lokale bedrijven blijkt dat de impact van de visserij in het algemeen op de werkgelegenheid in de verschillende visserijgemeenschappen groot is. En dan gaat het niet alleen om de hiervoor genoemde toeleverende en afnemende bedrijven, maar ook om plaatselijke supermarkten, bakkerijen, slagers die kotterbedrijven wekelijks voorzien van proviand, coöperaties met handelsartikelen (onder andere laarzen, kledij voor de bemanning, smeerolie etc.), en accountantskantoren.

\subsection{Discussie}

\subsubsection{Kwaliteit basisdata en scenario's}

De studie is gebaseerd op informatie vanuit het bedrijveninformatienet uit het jaar 2016. Hierbij is gebruik gemaakt van individuele data van 30 panelkotters die de 76 pulskotters representeren, dit is een goede steekproefdichtheid (38\%). Door ook met prijsscenario's te werken wordt inzicht gegeven in de gevoeligheid van de uitkomsten bij andere vis- en brandstofprijzen. 


\subsubsection{Visserijgedrag en handelingsperspectief}

Ondernemers zullen altijd zoeken naar optimale oplossingen die binnen hun bereik liggen, zo ook in de visserijsector. Dit betekent dat de sector zal reageren om de nadelige effecten zo veel mogelijk te beperken. Deze effecten zijn in de studie niet verder gekwantificeerd, ook omdat op korte termijn geen of weinig alternatieven voorhanden zijn, en daarmee de handelingsruimte voor vissers ook beperkt is.

\subsubsection{Effecten van andere beleidsmaatregelen (gesloten gebieden, aanlandplicht, brexit)}

In de studie is geen rekening gehouden met andere komende ontwikkelingen die invloed hebben op het voortbestaan van de visserijsector. Er zijn drie andere belangrijke ontwikkelingen die van grote invloed zijn voor de toekomst van de visserij:

- aanlandplicht

- brexit

- beperkte ruimte op zee

\section{Aanlandplicht}

De pulsvisserij werd beoordeeld als een relatief 'schone' visserij met 30-50\% minder discards (Taal en Klok, 2014). Dit betekent dus ook minder kosten voor de verwerking van discards. Uit onderzoek van Buisman et al. (2016) bleek dat de totale kosten van de aanlandplicht voor de sector circa 20-30 miljoen euro zouden bedragen. Sindsdien zijn er echter deeloplossingen ontwikkeld om de effecten van de aanlandplicht te beperken. Uitzonderingregels zijn inmiddels ontwikkeld voor toepassing van het Belgische paneel, en bij hoge overlevingskansen van vissen aan boord. Het is niet bekend wat nu de totale kosten van de aanlandplicht zullen zijn, waarmee dus ook niet bekend is hoe de kostenverhoging zal zijn bij omschakeling van puls naar boomkor. Het is wel duidelijk dat meer discards met hogere kosten gepaard zal gaan.

\section{Brexit}

Veel Nederlandse vissers vissen in Britse wateren. Er is nog veel onduidelijk over de consequenties en de maatregelen. Op dit moment lijkt het erop dat in elk geval in de Britse wateren niet met de puls gevist mag worden. Brexit zou ook kunnen betekenen dat deze visgronden niet meer benut mogen worden, en er dus minder ruimte voor de visserij resteert. Daarnaast zouden ook de quota evenredig kunnen worden verlaagd. Tenslotte kunnen er ook handelsbeperkingen ontstaan die nadelig zijn voor de visserijsector.

\section{Beperkte ruimte op zee}

Naast brexit zijn er ook gebieden die in het kader van natuurbehoud worden gesloten voor de visserij. Verder brengt ook de uitbreiding van windparken in de Noordzee beperkingen met zich mee. Deze ruimte claims maken dat de visserij beperkt wordt in haar mogelijkheden, maar de effecten van deze beperkingen op de mogelijkheden om over te stappen naar de boomkor zijn onduidelijk. 


\section{Conclusies}

Omvang van de pulsvisserij

De pulsvisserij is voor de Nederlandse visserij sector van groot belang. Dit blijkt uit het volgende:

1. De totale Nederlandse kottervloot bestaat uit 143 garnalenkotters en 137 kotters die voornamelijk platvis vangen. Van deze laatste groep zijn er 79 kotters met pulsontheffing die deze hebben benut. Daarnaast zijn er nog 5 pulsontheffingen die niet zijn ingezet.

2. De betreffende 79 pulskotters vingen in $201675 \%$ van de totale Nederlandse aanvoer van tong, $29 \%$ van de schol aanvoer en $40 \%$ van de overige aanvoer. De aanvoer van pulskotters is dus van groot belang voor vooral de tongvangsten.

3. De Nederlandse pulsvloot droeg in 2016 met 30,8 miljoen euro voor $38 \%$ bij aan het totale nettoresultaat van de kottervisserij, en voor $60 \%$ van de kottervisserij exclusief garnalen.

4. De directe werkgelegenheid van de pulsvloot is 540 tot $600 \mathrm{fte}$. Dit is exclusief de werkgelegenheid aan de wal voor toelevering, handel en verwerking, maar inclusief de walbemanning.

Economische gevolgen voor kottersector bij een totaalverbod op pulsvisserij:

1. De omschakeling naar de boomkor resulteert in een forse verlaging van het economisch rendement per kotter en voor de gehele sector. Uitgaande van de situatie in 2016 zal het nettoresultaat per eurokotter iets meer dan 100.000 euro lager zijn en per grote kotter ongeveer 120.000 euro lager. Er wordt per zeedag $69 \%$ meer schol gevangen en $12 \%$ minder tong. Omdat in het jaar 2016 de visprijzen goed waren en de gasolieprijs nog relatief laag, zou na omschakeling het netto-overschot van beide typen kotters nog positief zijn.

2. Voor de Nederlandse pulsvloot betekent de omschakeling dat de arbeidsopbrengst (nettoresultaat plus de deellonen) 8,7 miljoen euro lager zal uitkomen (prijsniveau 2016).

3. De omschakeling heeft eveneens grote consequenties voor het brandstofverbruik en de $\mathrm{CO}_{2}-$ uitstoot. Het totale brandstofverbruik van de huidige pulsvloot neemt na omschakeling met $78 \%$ toe, met ook een evenredige toename van de $\mathrm{CO}_{2}$-uitstoot.

4. Omdat het jaar 2016 een gunstig jaar was zijn in de studie diverse prijsscenario's uitgewerkt. Bij het ongunstige prijsscenario (overeenkomend met de omstandigheden tijdens de periode 20122014) met lage schol- en tongprijzen en hoge brandstofprijzen is het resterende gemiddelde nettoresultaat per kotter na omschakeling naar boomkorvisserij ongeveer nihil, en is voor de totale Nederlandse pulsvloot het netto-overschot 11,5 miljoen euro lager en het deelloon ongeveer 10 miljoen euro lager, in totaal dus een daling van 21,5 miljoen euro.

5. De spreiding in financieel resultaat tussen bedrijven is echter groot. Bij het ongunstige scenario verkeert bijna de helft van de kotters in een situatie met een negatief netto-overschot, waarbij de continuïteitspositie van deze kotters in gevaar kan komen.

Overige effecten

1. In het verleden is er een lange periode geweest (2002 tot en met 2011) met financieel moeilijke jaren voor de sector. Vanaf het jaar 2011 hebben 42 kotters gebruik kunnen maken van de pulsontheffing, daardoor een meer rendabele bedrijfsvoering weten te bereiken en logischerwijs de solvabiliteit weten te verbeteren. In 2014 volgde de tweede groep bedrijven met een pulsontheffing maar echter met 3 jaar achterstand ten opzichte van de eerste groep. Deze laatste groep bedrijven zal wellicht als eerste in financiële problemen komen bij een volledige stopzetting van de pulsvisserij.

2. De totale investeringen in pulstuig hebben voor de Nederlandse pulsvloot ruim 25 miljoen euro bedragen. De fiscale afschrijvingstermijn is gemiddeld 5 jaar, zodat een groot deel inmiddels afgeschreven is.

3. Naast de invloed op het bedrijfsresultaat merkt ook de bemanning direct de gevolgen van dalende resultaten. Het gevaar is aanwezig dat de beloning zo laag wordt dat het zeer moeilijk wordt om gekwalificeerde bemanning aan te trekken. Afhankelijk van de prijsscenario's neemt het deelloon af met $11 \%$ bij scenario $A$ (gunstig) tot $36 \%$ bij scenario D (ongunstig). 
4. De effecten zijn het grootst voor bemanning en bedrijf. Als gevolg van de omschakeling zal er minder of geen ruimte zijn voor vervangingsinvesteringen en nieuwbouw. De effecten voor toeleverende en afnemende bedrijven zijn moeilijk te kwantificeren. Coöperaties zullen te maken krijgen met extra vraag naar boomkortuigen, maar ook minder onderhoud voor pulstuigen. De handels- en verwerkingsbedrijven zullen in eerste instantie met meer schol- en minder tongaanvoer te maken krijgen.

5. Pulsvisserij gaat gepaard met minder discards. In het kader van de aanlandplicht betekent dit dus meer discards bij de boomkor. Dit gaat met hogere kosten gepaard.

6. In de studie is geen rekening gehouden met verandering van ondernemersgedrag. Ondernemers zullen altijd zoeken naar optimale oplossingen die binnen hun bereik liggen. Dit betekent dat de sector zal reageren om de nadelige effecten zo veel mogelijk te beperken. Deze effecten zijn in de studie niet verder gekwantificeerd. 


\section{Literatuur en websites}

- Bedrijveninformatienet. Visserij in Cijfers. Den Haag, Wageningen Economic Research.

- Council of the European Union. 1998. Council Regulation (EC) No 850/98 of 30 March 1998 for the conservation of fishery resources through technical measures for the protection of juveniles of marine organisms.

- Europese Commissie (2014). Het gemeenschappelijk visserijbeleid (GVB) Brussel, Commissie van de Europese Gemeenschappen.

- Haasnoot, T., M. Kraan, en S.R. Bush (2016), Fishing gear transitions: lessons from the Dutch flatfish pulse trawl. ICES Journal of Marine Science (2016), 73(4), 1235-1243.

- Oostenbrugge, H. van, Mol, A., Klok, A., Op de Weegh, J. \& Hoekstra, G. (2018) Economische aspecten puls. Rapport 2018-024, Den Haag, Wageningen Economic Research, 2018.

- Poos, J. J., Turenhout, M. N. J., van Oostenbrugge, H., and Rijnsdorp, A. D. 2013. Adaptive response of beam trawl fishers to rising fuel cost - ICES Journal of Marine Science, 70: 675- 684.

- Quirijns et al., (2013) Platvis pulsvisserij. Resultaten onderzoek en kennisleemtes, Rapport C193/13, IJmuiden, Imares Wageningen UR.

- Rijksoverheid. 2014. Agreement to double pulse trawl licenses. http://www.government.nl/news/2014/02/18/agreement-to-double-pulse-trawl-licences.html

- Rijnsdorp A. D. Rasenberg M. M. M. Wilms I. 2014. Proposal for pulse trawl research. http://www.nsrac.org/wp-content/uploads/2014/10/20141107-Proposed-research-agendapulsefishing_17112014.pdf

- Taal, C. en A. Klok. Pulswing. Ontwikkeling van een vistuig voor platvis waarin pulstechniek met de sumwing is gecombineerd. Rapport LEI 2014 - 039, LEI Wageningen UR, december 2014.

- Teal, L.R., J. Depestele, B. O’Neill, J.A.M. Craeymeersch, P.D. v. Denderen, R. Parker, K. J. Perdon, H. Polet, M. M. M. Rasenberg, B. Vanelslander and A.D. Rijnsdorp. (2014). Effects of beam and pulse trawling on the benthic ecosystem, Rapport C098/14, IMARES Wageningen University \& Research, Ijmuiden, 2014.

- Website www.visserijincijfers.nl

- Turenhout, M., B.W. Zaalmink, W.J. Strietman en K. Hamonn. Pulse fisheries in the Netherlands. Economic and spatial impact study. Report 2016-104, Wageningen Economic Research, 2016. 


\section{Bijlage 1}

Resultaat scenario A (euro per kotter)

\begin{tabular}{|c|c|c|c|c|c|c|}
\hline & \multicolumn{3}{|c|}{ Eurokotter } & \multicolumn{3}{|c|}{ Grote kotter } \\
\hline & basis & na omschakeling & verschil & basis & na omschakeling & verschil \\
\hline Netto-overschot & 328320 & 270979 & -57341 & 647163 & 591544 & -55619 \\
\hline Totale kosten & 1105007 & 1103308 & -1698 & 1942308 & 2107366 & 165058 \\
\hline Brandstofkosten & 129733 & 215428 & 85696 & 363488 & 652459 & 288971 \\
\hline Deelloon & 436394 & 378500 & -57894 & 696797 & 624984 & -71813 \\
\hline Deelloon per bemanning & 108938 & 94329 & -14608 & 116944 & 105060 & -11885 \\
\hline kg schol & 52651 & 77234 & 24583 & 307759 & 451205 & 143446 \\
\hline besomming schol & 102957 & 150892 & 47935 & 627641 & 915036 & 287395 \\
\hline
\end{tabular}

Resultaat scenario B (euro per kotter)

\begin{tabular}{|c|c|c|c|c|c|c|}
\hline & \multicolumn{3}{|c|}{ Eurokotter } & \multicolumn{3}{|c|}{ Grote kotter } \\
\hline Netto-overschot & 287930 & 204576 & -83354 & 535895 & 392558 & -143337 \\
\hline Totale kosten & 1145397 & 1169712 & 24315 & 2053576 & 2306352 & 252776 \\
\hline Brandstofkosten & 195367 & 324418 & 129051 & 547384 & 982552 & 435168 \\
\hline Deelloon & 410140 & 334904 & -75236 & 623238 & 492947 & -130292 \\
\hline Deelloon per bemanning & 102398 & 83434 & -18964 & 104509 & 82807 & -21703 \\
\hline kg schol & 52651 & 77234 & 24583 & 307759 & 451205 & 143446 \\
\hline besomming schol & 102957 & 150892 & 47935 & 627641 & 915036 & 287395 \\
\hline
\end{tabular}


Resultaat scenario C (euro per kotter)

\begin{tabular}{|c|c|c|c|c|c|c|}
\hline & \multicolumn{3}{|c|}{ Eurokotter } & \multicolumn{3}{|c|}{ Grote kotter } \\
\hline & basis & na omschakeling & verschil & basis & na omschakeling & verschil \\
\hline Netto-overschot & 169468 & 117986 & -51482 & 288523 & 198800 & -89723 \\
\hline Totale kosten & 999443 & 1001868 & 2425 & 1704145 & 1847201 & 143056 \\
\hline Brandstofkosten & 130062 & 215975 & 85913 & 364410 & 654115 & 289704 \\
\hline Deelloon & 330496 & 276508 & -53988 & 457707 & 363158 & -94549 \\
\hline Deelloon per bemanning & 82360 & 68752 & -13608 & 76595 & 60837 & -15758 \\
\hline kg schol & 52651 & 77234 & 24583 & 307759 & 451205 & 143446 \\
\hline besomming schol & 66905 & 98055 & 31150 & 407863 & 594622 & 186759 \\
\hline
\end{tabular}

Resultaat scenario D (euro per kotter)

\begin{tabular}{|c|c|c|c|c|c|c|}
\hline & \multicolumn{3}{|c|}{ Eurokotter } & \multicolumn{3}{|c|}{ Grote kotter } \\
\hline & basis & na omschakeling & verschil & basis & na omschakeling & verschil \\
\hline Netto-overschot & 129280 & 51916 & -77365 & 177814 & 813 & -177001 \\
\hline Totale kosten & 1039630 & 1067938 & 28308 & 1814855 & 2045189 & 230334 \\
\hline Brandstofkosten & 195367 & 324418 & 129051 & 547384 & 982552 & 435168 \\
\hline Deelloon & 304374 & 233131 & -71243 & 384517 & 231784 & -152734 \\
\hline Deelloon per bemanning & 75853 & 57912 & -17941 & 64223 & 38696 & -25527 \\
\hline kg schol & 52651 & 77234 & 24583 & 307759 & 451205 & 143446 \\
\hline besomming schol & 66905 & 98055 & 31150 & 407863 & 594622 & 186759 \\
\hline
\end{tabular}


Wageningen Economic Research Postbus 29703

2502 LS Den Haag

T 0703358330

Ecommunications.ssg@wur.nl

www.wur.nl/economic-research

Wageningen Economic Research NOTA

2018-044
De missie van Wageningen University \& Research is 'To explore the potential of nature to improve the quality of life'. Binnen Wageningen University \& Research bundelen Wageningen University en gespecialiseerde onderzoeksinstituten van Stichting Wageningen Research hun krachten om bij te dragen aan de oplossing van belangrijke vragen in het domein van gezonde voeding en leefomgeving. Met ongeveer 30 vestigingen, 5.000 medewerkers en 10.000 studenten behoort Wageningen University \& Research wereldwijd tot de aansprekende kennisinstellingen binnen haar domein. De integrale benadering van de vraagstukken en de samenwerking tussen verschillende disciplines vormen het hart van de unieke Wageningen aanpak. 



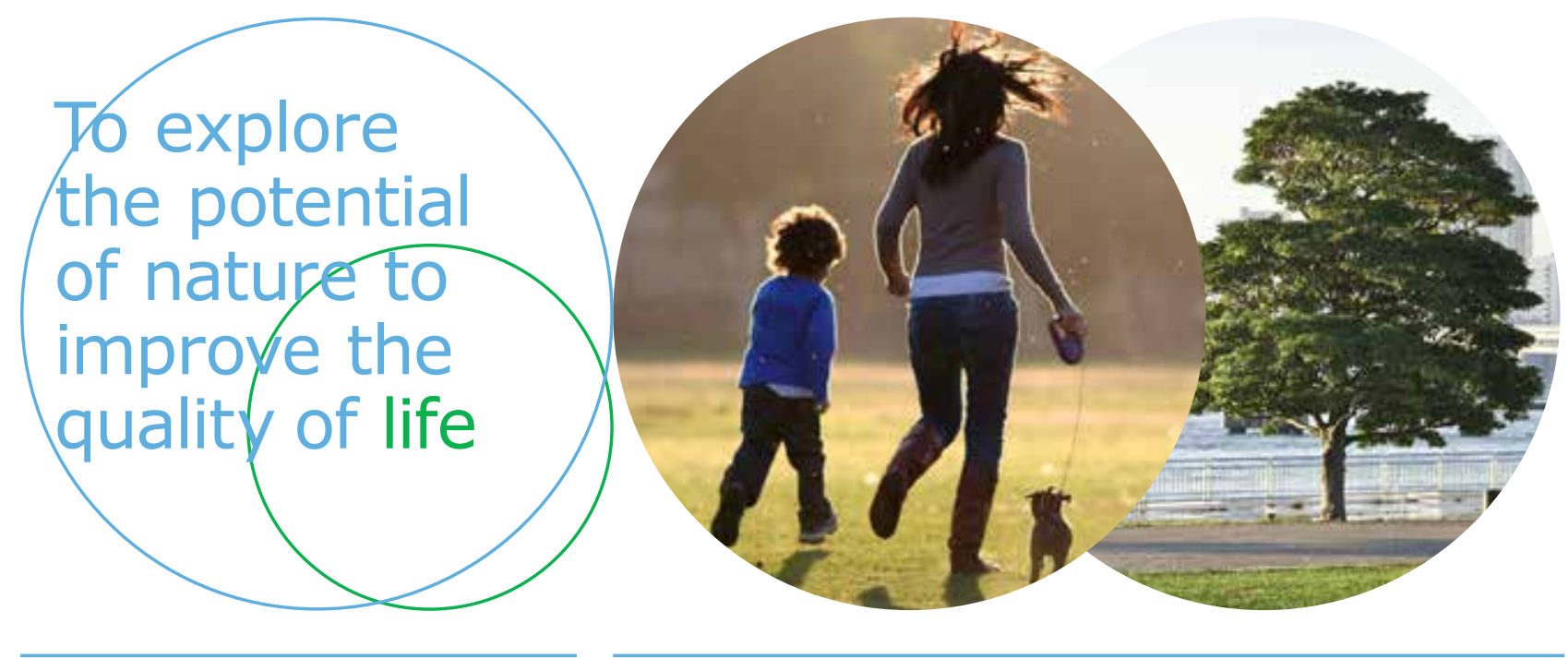

Wageningen Economic Research Postbus 29703

2502 LS Den Haag

E communications.ssg@wur.nl

$\mathrm{T}+31(0) 703358330$

www.wur.nl/economic-research

Nota 2018-044
De missie van Wageningen University \& Research is 'To explore the potential of nature to improve the quality of life'. Binnen Wageningen University \& Research bundelen Wageningen University en gespecialiseerde onderzoeksinstituten van Stichting Wageningen Research hun krachten om bij te dragen aan de oplossing van belangrijke vragen in het domein van gezonde voeding en leefomgeving. Met ongeveer 30 vestigingen, 5.000 medewerkers en 10.000 studenten behoort Wageningen University \& Research wereldwijd tot de aansprekende kennisinstellingen binnen haar domein. De integrale benadering van de vraagstukken en de samenwerking tussen verschillende disciplines vormen het hart van de unieke Wageningen aanpak. 